\title{
REVISED Host Directed Therapies for Tuberculous Meningitis
}

\section{[version 2; peer review: 2 approved]}

\section{Angharad G. Davis (Di)1-3, Joseph Donovan (D) 4,5, Marise Bremer3, Ronald Van Toorn', Johan Schoeman' ${ }^{6}$, Ariba Dadabhoy7, Rachel P.J. Lai ${ }^{2,8}$, Fiona V Cresswell (iD) 9,10, David R Boulware (D11, Robert J Wilkinson (iD) 1-3,8, Nguyen Thuy Thuong Thuong4,5, Guy E Thwaites (iD) 4, Nathan C Bahr (iD), Tuberculous Meningitis International Research Consortium}

\footnotetext{
${ }^{1}$ University College London, Gower Street, London, WC1E 6BT, UK

${ }^{2}$ The Francis Crick Institute, Midland Road, London, NW1 1AT, UK

${ }^{3}$ Wellcome Centre for Infectious Diseases Research in Africa, Institute of Infectious Disease and Molecular Medicine, University of Cape Town, Observatory, 7925, South Africa

${ }^{4}$ Oxford University Clinical Research Unit, Centre for Tropical Medicine, Ho Chi Minh City, Vietnam

${ }^{5}$ Centre for Tropical Medicine and Global Health, Nuffield Department of Medicine, University of Oxford, Oxford, UK

${ }^{6}$ Department of Pediatrics and Child Health, Stellenbosch University, Cape Town, 7505, South Africa

${ }^{7}$ Division of Infectious Diseases, Department of Medicine, University of Kansas, Kansas City, KS, USA

${ }^{8}$ Department of Infectious Diseases, Imperial College London, London, W12 0NN, UK

${ }^{9}$ Department of Clinical Research, London School of Hygiene and Tropical Medicine, London, WC1E 7HT, UK

${ }^{10}$ Infectious Diseases Institute, Makerere University, Kampala, Uganda

${ }^{11}$ Division of Infectious Diseases and International Medicine, Department of Medicine, University of Minnesota, Minneapolis, MN, USA
}

V2 First published: 23 Dec 2020, 5:292

https://doi.org/10.12688/wellcomeopenres.16474.1

Latest published: 01 Jul 2021, 5:292

https://doi.org/10.12688/wellcomeopenres.16474.2

\section{Abstract}

A dysregulated host immune response significantly contributes to morbidity and mortality in tuberculous meningitis (TBM). Effective host directed therapies (HDTs) are critical to improve survival and clinical outcomes. Currently only one HDT, dexamethasone, is proven to improve mortality. However, there is no evidence dexamethasone reduces morbidity, how it reduces mortality is uncertain, and it has no proven benefit in HIV co-infected individuals. Further research on these aspects of its use, as well as alternative HDTs such as aspirin, thalidomide and other immunomodulatory drugs is needed. Based on new knowledge from pathogenesis studies, repurposed therapeutics which act upon small molecule drug targets may also have a role in TBM. Here we review existing literature investigating HDTs in TBM, and propose new rationale for the use of novel and repurposed drugs. We also discuss host variable responses and evidence to support a personalised approach to HDTs in TBM.

Keywords

Tuberculous Meningitis, Host Directed Therapies, Dexamethasone

\section{Open Peer Review}

Approval Status

1 2

version 2

(revision)

01 Jul 2021

version 1

23 Dec 2020

1. Fabrice Bonnet, University of Bordeaux, Bordeaux, France

2. Vishwanath Venketaraman (D), Western

University of Health Sciences, Pomona, USA Any reports and responses or comments on the article can be found at the end of the article. 


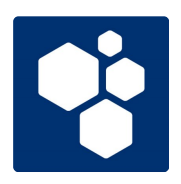

This article is included in the Wellcome Centre

for Infectious Diseases Research in Africa

(CIDRI-Africa) gateway.

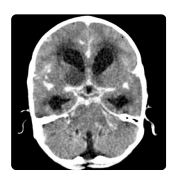

This article is included in the Tuberculous

Meningitis International Research Consortium

collection.

Corresponding author: Angharad G. Davis (angharadgracedavis@gmail.com)

Author roles: Davis AG: Conceptualization, Methodology, Supervision, Visualization, Writing - Original Draft Preparation, Writing Review \& Editing; Donovan J: Writing - Original Draft Preparation, Writing - Review \& Editing; Bremer M: Writing - Original Draft Preparation; Van Toorn R: Writing - Original Draft Preparation, Writing - Review \& Editing; Schoeman J: Writing - Original Draft Preparation, Writing - Review \& Editing; Dadabhoy A: Writing - Original Draft Preparation; Lai RPJ: Writing - Review \& Editing; Cresswell FV: Writing - Review \& Editing; Boulware DR: Writing - Review \& Editing; Wilkinson RJ: Conceptualization, Supervision, Writing - Review \& Editing; Thuong NTT: Writing - Original Draft Preparation, Writing - Review \& Editing; Thwaites GE: Conceptualization, Supervision, Writing - Review \& Editing; Bahr NC: Conceptualization, Supervision, Writing - Original Draft Preparation, Writing - Review \& Editing;

Competing interests: No competing interests were disclosed.

Grant information: This work was supported by the Wellcome Trust through a UCL Wellcome Trust PhD Programme for Clinicians Fellowship to AGD [175479]; support for GT and JD [110179]; a Wellcome International Intermediate Fellowship to NTTT [206724]; a Wellcome Clinical PhD Fellowship to FVC [210772]; support for RJW [104803; 203135] and funding for the Francis Crick Institute [FC0010218]. RL is supported by a MRC CDA Fellowship [MRC/R008922/1]. DRB is supported by the National Institutes of Neurological Diseases and Stroke of the National Institutes of Health [R01NS086312]. RJW receives support from Francis Crick Institute, which is funded by UKRI [FC0010218]; Wellcome [FC0010218] and CRUK [FC0010218]. He also receives support from Meningitis Now and NIH [R01AI45436]. NCB is supported by the National Institutes of Neurological Diseases and Stroke of the National Institutes of Health [K23NS110470].

The funders had no role in study design, data collection and analysis, decision to publish, or preparation of the manuscript.

Copyright: (c) 2021 Davis AG et al. This is an open access article distributed under the terms of the Creative Commons Attribution License , which permits unrestricted use, distribution, and reproduction in any medium, provided the original work is properly cited.

How to cite this article: Davis AG, Donovan ], Bremer $\mathrm{M}$ et al. Host Directed Therapies for Tuberculous Meningitis [version 2; peer review: 2 approved] Wellcome Open Research 2021, 5:292 https://doi.org/10.12688/wellcomeopenres.16474.2

First published: 23 Dec 2020, 5:292 https://doi.org/10.12688/wellcomeopenres.16474.1 


\section{REVISED Amendments from Version 1}

Structure

- Paragraph sub-headings have been changes

In Dexamethasone subsection:

- Details on study controls in the references dexamethasone studies have been added following comments from reviewer 1

- We have added a comment on CSF cytokines as a maker of cerebral inflammation following comments from reviewer 1

- The issue of dexamethasone dosage (and of rifampicin induction) and of the use of other corticosteroids has been commented on within this section.

In Aspirin subsection:

- Further detail in anticipated anti-inflammatory effect of aspirin has been added at request of reviewer 1 .

\section{In Immunomodulatory subsection:}

- In Table 2, the following references have been added to include additional information on adalimumab:

Adalimumab treatment may replace or enhance the activity of steroids in steroid-refractory tuberculous meningitis. Lee HS, Lee Y, Lee SO, Choi SH, Kim YS, Woo JH, Kim SH. J Infect Chemother. 2012 Aug;18(4):555-7

Adalimumab for Corticosteroid and Infliximab-Resistant Immune Reconstitution Inflammatory Syndrome in the Setting of TB/HIV Coinfection. Lwin N, Boyle M, Davis JS. Open Forum Infect Dis. 2018 Jan 30;5(2):ofy027

Chapter Future Pathways:

- The subsection on statin therapy has been shortened.

Subsection on host response:

- The discussion regarding the LTA4H gene and the response to dexamethasone has been expanded following comments from reviewer 1 .

Any further responses from the reviewers can be found at the end of the article

\section{Introduction}

Clinical outcomes in tuberculous meningitis (TBM) depend upon both killing Mycobacterium tuberculosis (M.tb) and managing host inflammatory response. Antimicrobial drug therapy for TBM has been adapted from that used for pulmonary tuberculosis (TB); four drugs are given initially, with subsequent tapering to two or three drugs (in drug-susceptible TBM, dependent on local guidelines) for continuation of therapy up to one year. Yet the host immune response may be dysregulated, and contributes to the poor outcomes associated with TBM. Host directed therapies (HDT) seek to control this host response and reduce death and neurological injury.

The discovery and assessment of new therapeutics in TBM has been a neglected area; this includes the development of bespoke antitubercular drug regimens which account for differing ability of drugs to penetrate the central nervous system, and the design of HDTs which counter dysregulated immune responses to M.tb within the central nervous system. In fact, corticosteroids are the only widely used host directed therapy in TBM with any proven benefit in both adults ${ }^{1}$ and children ${ }^{2}$. In adults, in particular, questions around their clinical use remain including whether they have a role in improving outcomes in HIV-associated TBM and the mechanisms by which they improve survival. Clinical trials to assess the efficacy of other HDTs including aspirin and thalidomide have been conducted, however there is not yet conclusive evidence to suggest when, with whom and at what dose they may be effective. New knowledge from studies uncovering mechanisms of inflammation and brain injury may also allow for a directed approach to modulating the host response. Similarly studies aiming to contribute knowledge of factors at play which influence variability in the host may lead us away from a 'one size fits all' therapeutic approach.

We review the evidence on currently used HDTs in TBM and suggest potential therapeutics based on pathogenesis studies and drawing from knowledge and experience in other forms of tuberculosis and neuroinflammatory conditions. We will review work which has contributed to our understanding of variation in host response and discuss how this knowledge might be harnessed to design a personalised approach to the use of HDT in TBM.

\section{Existing Host Directed Therapies for Tuberculous Meningitis \\ Dexamethasone}

Adjunctive corticosteroids reduce mortality from TBM, at least in the short term ${ }^{1,3,4}$. The mechanism through which corticosteroids confer clinical benefit is unclear, although reduction in intracerebral inflammation seems most likely. Glucocorticoids bind to and activate the glucocorticoid receptor of macrophages and other cells, interfering with inflammatory mediator transcription and expression ${ }^{5}$. Additional indirect genomic effects of inhibition of pro-inflammatory transcription factors such as activator protein-1, and non-genomic mechanisms further mediate glucocorticoid anti-inflammatory effects ${ }^{6-9}$.

Murine studies suggest M.tb induces activation of the microglial NLRP3 inflammasome, a multimolecular immune complex of receptors and sensors that mediates innate immune responses and induces inflammation via pro-inflammatory caspases and cytokines; a process inhibited by dexamethasone ${ }^{10,11}$. In TBM, pro-inflammatory cerebrospinal fluid (CSF) cytokine concentrations are acutely elevated, although therapeutically reducing these concentrations may not be clinically beneficial. In a study of 16 individuals with TBM in India, concentrations of tumor necrosis factor (TNF)- $\alpha$, interleukin (IL)-1 $\beta$, IL-6, IL-8, IL-10 were elevated in TBM vs. controls (10 non-neurological patients undergoing spinal anaesthesia due to obstructive uropathy), and declined during TB treatment, yet cytokine concentrations were not related to disease severity, brain magnetic resonance imaging (MRI) abnormalities or clinical outcome ${ }^{12}$. In a paediatric study $(n=30)$, CSF TNF- $\alpha$, IL- $1 \beta$, and interferon (IFN)-gamma concentrations were elevated in acute TBM, but again did not correlate with disease severity, nor were they influenced by corticosteroid administration ${ }^{13}$. However in a 
large study of clinical and intracerebral inflammatory phenotype and 9-month survival in adults with TBM from Vietnam, multiple pro-inflammatory and anti-inflammatory CSF cytokines were significantly reduced in HIV uninfected individuals who died vs. in HIV uninfected who survived ${ }^{14}$. This effect (lower pro-inflammatory cytokines in individuals who died) was not seen in HIV co-infection.

In 545 Vietnamese individuals $>14$ years recruited to a randomized placebo-controlled trial of dexamethasone for TBM, dexamethasone was associated with a reduced risk of death (relative risk $0.69, \mathrm{p}=0.01)^{1}$. In a representative subset of this study, dexamethasone did not significantly alter tested CSF cytokines (TNF- $\alpha$, IL-1 $\beta$, IL-6, IL-8, IL-10, IL-12) over time vs. placebo ${ }^{15}$. CSF concentrations of IL-6, IL-8, and IL-10 fell slowly after commencement of anti-TB chemotherapy, and TNF- $\alpha$ fell rapidly, all irrespective of dexamethasone treatment. In a subgroup of HIV uninfected adults $(n=37)$, dexamethasone significantly reduced CSF matrix metalloproteinase-9 (MMP-9) in follow up samples taken after a median 5 days of treatment ${ }^{16}$. CSF cytokine concentration measurement is frequently used as a proxy for measurement for intracerebral inflammation. Further work is required to determine whether the protective effect of dexamethasone correlates with a measurable reduction in intracerebral inflammation.

International guidelines recommend adjunctive corticosteroids for TBM management ${ }^{17}$. Corticosteroid use in TBM is commonplace, dexamethasone is commonly used as it is affordable and widely available although the optimal corticosteroid preparation, dose, and route of administration are unknown ${ }^{18}$. Issues with prolonged intravenous therapy, access to intravenous therapy, and pill burden for oral therapy, all require consideration when designing clinical trials of new corticosteroid regimens. Whether beneficial therapeutic effects extend to HIV co-infected individuals is uncertain. In a HIV-positive subgroup $(n=98)$ from a randomized trial of adjunctive corticosteroids for TBM in Vietnamese adults, dexamethasone was associated with a non-significant trend towards improved survival ${ }^{1}$. Subsequently, a study of adults with HIV-associated TBM showed global increase in pro-inflammatory cytokine concentrations, running counter to theory that immunosuppressed HIV co-infected individuals have lower intracerebral inflammation ${ }^{14}$. A multicentre randomized controlled trial of adjunctive corticosteroids for HIV co-infected adults with TBM is currently underway in Vietnam and Indonesia (NCT03092817) ${ }^{19}$.

Corticosteroids are frequently used to treat common neuro-complications of TBM; paradoxical reactions, and the immune reconstitution inflammatory syndrome (IRIS). Paradoxical neuro-inflammatory reactions, which occur despite appropriate anti-TB chemotherapy, may reflect host response to dead and dying bacteria ${ }^{20}$. TBM-IRIS is a common and often severe complication of starting anti-retroviral therapy (ART) in TBM, and is associated with high CSF neutrophil counts and a positive $M$. tuberculosis culture at presentation $^{21}$. Interestingly, a CSF inflammatory process, specifically high neutrophils and high TNF- $\alpha$ in combination with low IFN-gamma, predicted later TBM-IRIS in a study of 34 individual with TBM in South Africa ${ }^{21}$. Inflammasome activation appears to be involved in the development of TBM-IRIS, with matrix metalloproteinase (MMP)-9 a possible mediator of brain tissue damage $^{11}$. Whilst corticosteroids during the first 4 weeks after initiation of ART reduced TB-associated IRIS in HIV co-infected individuals in a trial in South Africa, individuals with TBM were excluded ${ }^{22}$. There are no randomized trials of corticosteroid therapy for TBM-IRIS, nor for paradoxical neurological reactions in HIV uninfected individuals. Table 1 summarises the current evidence for dexamethasone use in TBM, as well as for other host-directed therapies.

In childhood TBM, benefit from corticosteroids has been demonstrated in a number of studies ${ }^{2,23-25}$. Unlike in adults, improvement in disability, albeit moderate, is described ${ }^{3}$. Dosage and duration however is debated and in randomized trials dosage has varied between $1 \mathrm{mg} / \mathrm{kg}$ and $4 \mathrm{mg} / \mathrm{kg}$ daily, for 3-4 weeks. One trial compared three dosage regimens; $2 \mathrm{mg} / \mathrm{kg} /$ day over 4 weeks vs $4 \mathrm{mg} / \mathrm{k} /$ day over 1 week and $2 \mathrm{mg} / \mathrm{k} /$ day for the next 3 weeks vs $4 \mathrm{mg} / \mathrm{kg} /$ day over 4 weeks $^{26}$. In each group the initial 4 weeks was following by 4 weeks of tapering. There was no difference in mortality between groups, however prolonged periods of higher dose prednisolone were associated with new onset optic neuropathy and hydrocephalus ${ }^{26}$. These findings highlight the delicate balance between moderating host immunity, and avoiding the occurrence of adverse events. Further studies are needed to identify ideal dosage regimen, as well as explore host variability in response to corticosteroids in childhood TBM.

\section{Promising Host Directed Therapies for Tuberculous Meningitis}

Aspirin

Cerebral infarction occurs in $25-71 \%$ of TBM $\operatorname{cases}^{27,28}$, and stroke was associated with a two-fold increase in mortality in a recent meta-analysis ${ }^{29}$. The inflammatory state occurring in TBM contributes to the pathogenesis of stroke. A prospective study of 146 TBM patients demonstrated an acute phase inflammatory response with significantly elevated cytokines (e.g. IL-2, IL-4, IL-6, IL-1 $\beta$, IFN- $\gamma$, TNF- $\alpha$ ) in blood and $\mathrm{CSF}^{30}$. A hypercoagulable state was reflected by elevated protein $\mathrm{C}$, factor VII, plasminogen activator inhibitor-1 and anticardiolipin antibodies, as well as decreased protein $\mathrm{S}$ in a case series of 16 children. Bleeding times were also markedly shorter and platelet counts remained markedly raised in this subgroup $^{31}$. Hypercoagulability has been shown to occur in adults with pulmonary tuberculosis, and may also contribute to pathogenesis of stroke in TBM. Local intra- and extra-vascular factors contributes to TBM pathogenesis, most significantly in the form of cerebral vasculitis secondary to inflammatory infiltrates; initially believed to be directly due to tubercle bacilli implantation, now known to correlate with the inflammatory exudate in the basal cisterns and subarachnoid space $^{32,33}$. The significance of intravascular thrombosis is still unclear. While thrombosis might be common in the context of vasculitis, autopsies on TBM patients failed to demonstrate 
Table 1. Summary of clinical studies investigating the efficacy of dexamethasone, aspirin and thalidomide in TBM.

\begin{tabular}{|c|c|c|c|c|c|}
\hline Reference & $\begin{array}{l}\text { Intervention } \\
\text { (drug, dose, } \\
\text { duration) }\end{array}$ & Study design & Population & $\begin{array}{l}\text { Primary } \\
\text { outcome }\end{array}$ & Key findings \\
\hline $\mathrm{Mai}^{27}$ & $\begin{array}{l}\text { Aspirin } 81 \text { mg vs. } 1000 \\
\text { mg vs. placebo for } 60 \\
\text { days }\end{array}$ & $\begin{array}{l}\text { RCT: double- } \\
\text { blind, } \\
\text { Placebo } \\
\text { controlled }\end{array}$ & $\begin{array}{l}\text { Adults } \\
\text { Non-HIV, } \\
\text { Vietnam } \\
\mathrm{n}=120\end{array}$ & $\begin{array}{l}\text { Mortality } \\
\text { or Stroke }\end{array}$ & $\begin{array}{l}\text { No difference in 2-month mortality. } \\
\text { Subgroup analysis showed reduction in infarcts } \\
\text { and death with aspirin } 81 \mathrm{mg}(15 \%) \text { and } 1000 \\
\text { mg }(11 \%) \text { compared to placebo (34\%); } p=0.06\end{array}$ \\
\hline Misra ${ }^{34}$ & $\begin{array}{l}\text { Aspirin } 150 \mathrm{mg} \text { vs. } \\
\text { placebo }\end{array}$ & $\begin{array}{l}\text { RCT: Placebo } \\
\text { controlled }\end{array}$ & $\begin{array}{l}\text { Adults } \\
\mathrm{n}=118\end{array}$ & $\begin{array}{l}\text { Mortality } \\
\text { or Stroke }\end{array}$ & $\begin{array}{l}\text { Decreased } 3 \text {-month mortality }(21.7 \%) \text { vs } \\
\text { placebo }(43.4 \%) \text {; Odds Ratio }=3.17,95 \% \mathrm{CI} \\
1.21-8.31 . \text { Aspirin resulted in absolute risk } \\
\text { reduction of stroke in } 19.1 \% \text { and significant } \\
\text { reduction in mortality compared to placebo } \\
(21.7 \% \text { vs } 43.4 \%, p=0.02)\end{array}$ \\
\hline Misra 35 & Aspirin 150mg & $\begin{array}{l}\text { Retrospective } \\
\text { cohort }\end{array}$ & $n=135$ & Mortality & $\begin{array}{l}\text { Non-statistical reduction in deaths }(25 \%) \text { at } 3 \\
\text { months compared to standard TB treatment } \\
(17 \%) \text {. }\end{array}$ \\
\hline Schoeman 36 & $\begin{array}{l}\text { Aspirin } 75 \mathrm{mg} \text { or } \\
100 \mathrm{mg} / \mathrm{kg}\end{array}$ & $\mathrm{RCT}$ & $\begin{array}{l}\text { Children } \\
n=146\end{array}$ & & $\begin{array}{l}\text { No improved neurological or cognitive } \\
\text { outcomes or survival with aspirin }\end{array}$ \\
\hline Schoeman ${ }^{37}$ & $\begin{array}{l}\text { Thalidomide } 6 \mathrm{mg} / \mathrm{kg} \\
12 \mathrm{mg} / \mathrm{kg}, \text { or } 24 \mathrm{mg} / \mathrm{kg}\end{array}$ & $\begin{array}{l}\text { Dose escalating } \\
\text { Pilot study }\end{array}$ & $\begin{array}{l}\text { Children } \\
n=15\end{array}$ & $\begin{array}{l}\text { Safety and } \\
\text { tolerability }\end{array}$ & Reduce CSF TNF-a in children with stage 2 TBM \\
\hline Schoeman 38 & $\begin{array}{l}\text { Thalidomide } 24 \mathrm{mg} / \mathrm{kg} \\
\text { for } 1 \text { month }\end{array}$ & $\begin{array}{l}\text { RCT: Double } \\
\text { blinded }\end{array}$ & $\begin{array}{l}\text { Children } \\
n=47\end{array}$ & & $\begin{array}{l}\text { Discontinued prematurely due to side effects } \\
\text { and deaths in thalidomide arm }\end{array}$ \\
\hline Thwaites & Dexamethasone & $\begin{array}{l}\text { RCT: Double- } \\
\text { blind Placebo } \\
\text { controlled }\end{array}$ & $\begin{array}{l}\text { Adult } \\
\mathrm{n}=545 \\
\text { HIV and } \\
\text { non-HIV }\end{array}$ & Mortality & $\begin{array}{l}\text { Reduced risk of death through } 9 \text { months } \\
\text { (relative risk 0.69, } p=0.01 \text { ) with dexamethasone }\end{array}$ \\
\hline Simmons $^{15}$ & Dexamethasone & $\begin{array}{l}\text { RCT: Double- } \\
\text { blind Placebo } \\
\text { controlled }\end{array}$ & $\begin{array}{l}\text { Adult } \\
\mathrm{N}=87\end{array}$ & & $\begin{array}{l}\text { Dexamethasone did not significantly alter } \\
\text { tested CSF cytokines (TNF-a, IL-1 } \beta, \text { IL-6, IL-8, } \\
\text { IL-10, IL-12) over time vS. placebo }\end{array}$ \\
\hline
\end{tabular}

$\mathrm{RCT}=$ randomised clinical trial; $\mathrm{IL}=$ interleukin; TNF = tumor necrosis factor .

frequent arterial thrombosis ${ }^{32}$. Significant platelet dysfunction has also been demonstrated in TBM, manifesting as increased mean platelet volumes, platelet distribution width and platelet-large cell ratio ${ }^{39}$. These parameters are significantly associated with infarcts and suggests the use of antiplatelet agents in $\mathrm{TBM}^{39}$. Local intra- and extra-vascular factors contribute to TBM pathogenesis in the form of vasculitis due to bacilli infiltration. In an effort to reduce mortality and long-term neurological disability in TBM, aspirin is increasingly being studied due to its anti-inflammatory and inhibitory effects on platelet and thrombus production. In murine models, low dose aspirin $(3 \mathrm{mg} / \mathrm{kg})$ showed a systemic decrease in serum cytokines (e.g. TNF- $\alpha$, IL-6, IL-1 $\beta$ ) and late stage $T$ cell responses in M.tb infection. Aspirin also enhances $\mathrm{T}$ helper cell 1 responses for eliminating bacilli from lungs ${ }^{40}$. Aspirin contributes to the resolution of inflammation by generating 15-epi-lipoxims, resolvins and protectins, recognized for their anti-inflammatory as well as pro-resolving characteristics ${ }^{41}$ It is also well described how the drug inhibits pro-inflammatory prostanoid production via acetylation of $\mathrm{COX}^{42}$.
To date, three randomized controlled trials have investigated the role of aspirin in adult and paediatric TBM. In 118 adult TBM patients in India, aspirin resulted in absolute risk reduction of stroke in $19.1 \%$ and significant reduction in mortality compared to placebo (10 of $118(21.7 \%)$ versus 23 of $118(43.4 \%), \mathrm{p}=0.02)^{34}$. A randomised controlled trial of TBM involving children in South Africa $(n=146)$ could not establish improved neurological/cognitive outcomes or survival with ASA at doses of $75 \mathrm{mg}$ (low dose) or $100 \mathrm{mg} / \mathrm{kg} /$ day (high dose $)^{36}$. However, the developmental outcome of children on high dose ASA was similar to the placebo and low dose ASA groups, despite being younger of age and having higher baseline severity. This finding warrants further investigation of high-dose ASA in childhood TBM. A study of 120 Vietnamese adults with TBM demonstrated a reduction in death and new infarcts with the addition of $81 \mathrm{mg} / \mathrm{day}$ aspirin $(8$ of 36 or $22.2 \%$ ) and $1000 \mathrm{mg} /$ day aspirin (6 of 38 or $15.8 \%$ ), versus placebo (11 of 38 or $28.9 \%)^{27}$. Aspirin was associated with dose-dependent inhibition of thromboxane A2 and upregulation of pro-resolving protectins in the CSF. 
Another retrospective study by Misra et al. in India failed to validate clinical benefit, showing an insignificant reduction in deaths with the addition of $150 \mathrm{mg}$ aspirin as compared to standard anti-TB therapy ${ }^{35}$. However, $25 \%$ (11 of 135) of patients randomized to the aspirin arm had a complete recovery at 3 months versus $17.1 \%$ ( 7 of 135 ) in the standard treatment arm. In the three adult trials, corticosteroids were administered alone or in conjunction with aspirin with no adverse event signal found. None of these trials observed an increase in adverse events, but safety concerns with increasing doses of aspirin persist. Whilst these studies of adjunctive aspirin described varying results regarding morbidity and mortality, they paved the way for further large randomised controlled trials. The above described trials utilized a daily aspirin regimen duration or primary outcome measured at two to three months. A recent study utilized MRI to quantify baseline and follow up brain lesions in TB meningitis and found that $60 \%(n=48)$ of participants had the presence of acute infacts at enrolment, with only one new infact at follow up 2 months later ${ }^{43}$. This correlates to the acute phase in which most complications of TB meningitis occur and the window where meningeal inflammation and vasculitis needs to be treated. Phase 2 (NCT03927313) and 3 (NCT04145258) trials are currently underway to validate aspirin as a host-directed therapy. Given the insufficient evidence base, aspirin is not routinely used in most individuals with TBM.

\section{Thalidomide}

Thalidomide has a wide range of biological effects, due to its ability to interfere with the immune system, and depending on the cell type or pathway of activation. The inhibition of TNF- $\alpha$, which is produced primarily by macrophages and monocytes, accounts for most of the immunological effects of the drug. TNF- $\alpha$ performs a delicate balancing act during host response to mycobacterium tuberculosis infection, whereby on the one hand it is mandatory for keeping infection under control, but on the other hand, if produced at too high levels it induces a hyperinflammatory state resulting in severe tissue damage. The potential of thalidomide to activate T-cells, resulting in elevated production of IL2, IFN and TNF- $\alpha$, may potentially interfere with its anti-inflammatory properties ${ }^{44}$. In addition, thalidomide does not inhibit TNF- $\alpha$ produced by stimulated Tcells. The therapeutic effect of thalidomide therefore appears to be dose dependant since differing TNF- $\alpha$ concentrations will result in opposing physiological consequences.

Thalidomide has been shown to reduce CSF TNF- $\alpha$ experimentally in rabbits ${ }^{45}$ as well as in children with UK Medical Research Council (MRC) grade 2 TBM in a dose-escalating pilot study ${ }^{37}$. However, a double-blind, randomized trial of high dose thalidomide treatment $(24 \mathrm{mg} / \mathrm{kg} /$ day for 1 month) in children with grade 2 and $3 \mathrm{TBM}$ was discontinued due to side effects (skin rash, hepatitis, neutropenia or thrombocytopenia) and deaths in the thalidomide $\operatorname{arm}^{38}$.

The anti-inflammatory benefits of thalidomide (e.g. improved resolution of basal enhancement and tuberculomas) noted in both the pilot and randomized trials have led to more targeted studies, albeit at a much reduced dosage $(\leq 5 \mathrm{mg} / \mathrm{kg} /$ day $)$. Additionally, adjunctive thalidomide has been shown to be particularly effective in observational studies involving tuberculous brain abscesses ${ }^{46,47}$ and blindness-related to optochiasmatic arachnoiditis ${ }^{48,49}$. Adverse drug effects have been less of an issue in these situations. The life-threatening nature of these TBM sequelae as well as the anatomical location of the lesions, which precluded surgery, disqualified them from being included in trials. Nonetheless, the clinical improvements noted have been substantial. (Figure 1).

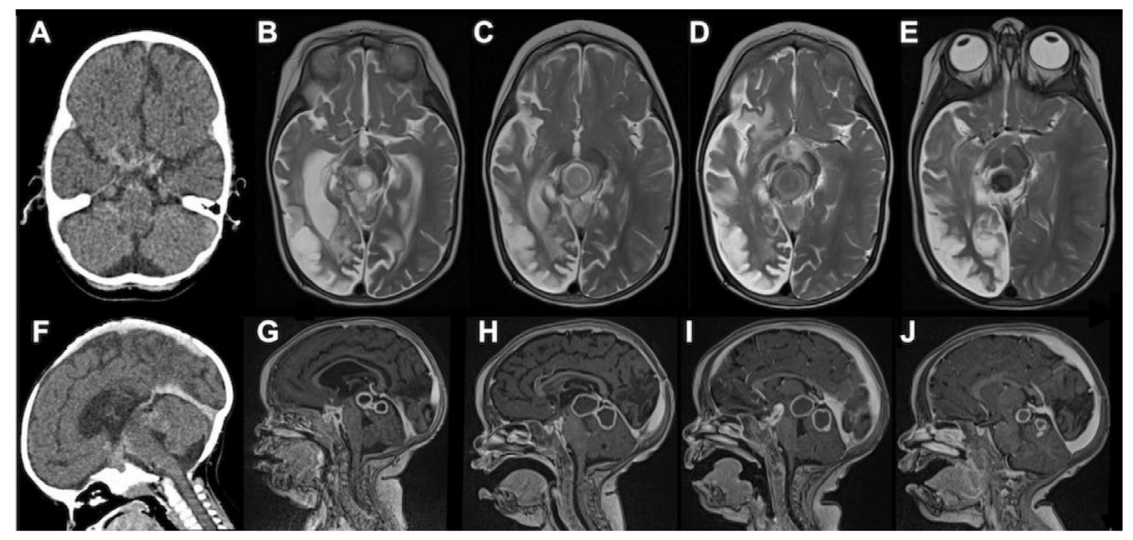

Figure 1. CT axial, MRI T2 axial, CT sagittal and MRI T1 post-gadolinium sagittal images at 3-4 month intervals of a 16-monthold HIV-infected female with stage III TBM. The initial CT axial and sagittal scans (A, F) showed a large right sided middle cerebral artery infarction, hydrocephalus as well as multiple small rim-enhancing foci in the prepontine cisterns. After 3 months of anti-TB and 2 months of anti-retroviral therapy, they presented with a depressed level of consciousness. MRI T2 axial (B) and MRI T1 post-gadolinium sagittal (G) demonstrated multiple TB abscesses in the interpeduncular, prepontine and chiasmic cisterns (paradoxical HIV related TB IRIS) as well as right cerebral hemisphere spongiotic changes (old infaction). Thalidomide was initiated following a poor response to 1 week of high dose corticosteroids. This resulted in rapid improvement in the level of consciousness, gradual decrease in the size of the TB abscesses and loss of T2 signal (i.e. inflammation), which is a marker of cure as it represents gradual calcification. (C-E \& $\mathbf{H}-\mathbf{J}$ ). 
When used, the duration of adjunctive thalidomide therapy should be guided by subsequent clinical and radiological responses. In TBM clinical improvement of mass lesions generally precedes radiological improvement due to a reduction in peri-lesional inflammation. Serial MRI T2-weighted studies have shown that evolution of the lesions from early stage "T2 bright" abscesses with oedema to "T2 black" represents a marker of cure $^{47}$. Regression is associated with fibrosis, mineralization (calcification) and eventually disappearance, usually with no residual structural abnormalities. T2-black granulomas may however persist for years in asymptomatic children. In most cases, cure is achieved after less than 3 months of adjunctive thalidomide therapy.

It is the authors experience that adjunctive thalidomide warrants consideration in the following TBM-related conditions: corticosteroid-unresponsive optochiasmatic arachnoiditis resulting in visual impairment and/or optic disc pallor; enlarging TB abscess despite corticosteroid therapy (TB-IRIS); large TB abscess/tuberculomas in critical brain regions (i.e. brainstem) that is not amenable to surgical drainage and not responding to corticosteroids; large dural-based TB abscess resulting in epilepsia partialis.

TNF- $\alpha$ has been shown to exert deleterious effects on capillaries already sensitized by exposure to mycobacterial products. The endarteritis, coupled with raised intracranial pressure because of edema and obstructive hydrocephalus, often leads to cerebral ischaemia/infarction. The value of low-dose adjunctive thalidomide in modifying the progressive endarteritis is yet to be explored.

\section{Immunomodulatory therapies}

Modulation of cytokines known to contribute to pathology is a potential strategy to support host defenses or control deleterious inflammation in TBM. In TBM a number of pro-inflammatory cytokines are thought to play a role in pathogenesis, including IL-2, IL-6, IL-1 $\beta$, IFN- $\gamma$ and TNF- $\alpha^{33}$. However, like in other neuroinflammatory conditions where cytokines such as IFN- $\gamma$ have opposing $\operatorname{roles}^{50}$, inhibition of these cytokines may not necessarily lead to improved outcomes and therefore caution must be exercised in exploring the potential drugs which inhibit these pro-inflammatory cytokines as candidate HDTs.

There are accumulating data on the role of the anti-TNF- $\alpha$ monoclonal antibodies infliximab and adalimumab and the soluble TNF- $\alpha$ receptor etanercept in TBM treatment. Although these agents are described as options for treating refractory paradoxical reactions involving the $\mathrm{CNS}^{51-54}$, they may also be responsible for latent $\mathrm{TB}$ reactivation and dissemination to the CNS in those where the drug is used to treat autoimmune conditions ${ }^{55}$. Anakinra is a human interleukin-1 receptor antagonist that blocks the biological activity of natural IL-1 and may also have a role in TBM. Anakinra demonstrated efficacy in one case of life-threatening protracted paradoxical inflammation in CNS TB where high dose corticosteroids failed ${ }^{56}$. Other immunomodulatory agents of interest include canakinumab and tocilizumab, human monoclonal antibodies inhibiting IL-1 and IL-6 respectively. In TBM, vasculitis occurs due to the proximity of the progressive exudative meningitis to the basal subarachnoid cistern and the circle of Willis. Cyclophosphamide, an alkylating cytotoxic drug is an effective drug in the treatment of primary cerebral vasculitis. Two case reports have described clinical improvement with the use of cyclophosphamide in TBM associated cerebral vasculitis ${ }^{57,58}$; however, its role as an effective treatment in this context needs further investigation particularly due to concerns over its potential adverse activity as a potent immunosuppressive drug. Table 2 summarises cases within the published literature where these agents have been used in the context of TBM; however, pre-clinical and clinical studies to systematically investigate the therapeutic effectiveness is required before they can be used more widely as adjunctive therapies in TBM.

\section{Potential Pathways for Future Host Directed Therapies for Tuberculous Meningitis}

Although host directed therapies are in use, they are limited in either efficacy or availability. Therefore the quest for more effective therapeutics remains ongoing. Here we discuss potential therapies which target pathways highlighted in recent pathogenesis studies, or draw on insights from other forms of TB or inflammatory conditions with shared mechanisms of pathogenesis (Figure 2).

\section{Statin Therapy Pathways}

HMG-CoA reductase inhibitors ('statins') are ubiquitously used in prevention and treatment of cardiovascular disease, but are also known to have immunomodulatory, anti-inflammatory and anti-oxidative properties. Several in vitro studies have demonstrated that statins enhance anti-inflammatory and inhibit pro-inflammatory functions in microglial cells and inhibit mechanisms involved in neurodegeneration ${ }^{59-62}$. Anti-inflammatory properties may be due to modulation of isoprenylation ${ }^{63}$ with downstream effects on inhibitory and stimulatory transcription pathways, or via allosteric inhibition of leucocyte function antigen (LFA)-1 integrin ${ }^{64}$ which is involved in the transmigration of activated $\mathrm{T}$ cells through the blood brain barrier. Neuroprotective effects may be due to modulation of excitotoxicity, vascular function, angiogenesis, and/or reduced oxidative damage through nitric oxide stimulas ${ }^{65,66}$. Importantly, some studies have shown increased neuronal death with higher concentrations of statins ${ }^{67-69}$.

The potential of statins to effect CNS inflammation and neurodegeneration in other conditions are of interest given the shared mechanistic pathways in TBM. For example, animal models of multiple sclerosis (MS) show that statins skew immune responses towards an anti-inflammatory T-helper cell 2 response, inhibiting pro-inflammatory cytokines IL-2, IL-12 and IFN- $\boldsymbol{\gamma}^{70}$. Patients with secondary progressive MS benefited from statin therapy ${ }^{71}$ with a phase 3 trial underway (NCT03387670). In a mouse model of traumatic brain injury, 
Table 2. Biologics and other immunomodulatory therapies in TBM; summary of published case reports.

\begin{tabular}{|c|c|c|c|c|}
\hline Reference & Drug & Dose & Mechanism & Clinical outcome \\
\hline Blackmore ${ }^{51}$ & Infliximab & $\begin{array}{l}10 \mathrm{mg} / \mathrm{kg} \text {, three } \\
\text { doses at monthly } \\
\text { intervals }\end{array}$ & Anti-TNF & $\begin{array}{l}\text { Given after } 4 \text { months due to ongoing clinical } \\
\text { deterioration, despite treatment with dexamethasone } \\
\text { and cyclophosphamide; resulted in clinical } \\
\text { improvement. }\end{array}$ \\
\hline Jorge $^{52}$ & Infliximab & $\begin{array}{l}10 \mathrm{mg} / \mathrm{kg} \text {, three } \\
\text { doses at monthly } \\
\text { intervals }\end{array}$ & Anti-TNF & $\begin{array}{l}\text { Young adult with juvenile idiopathic arthritis, treated } \\
\text { with infliximab developed disseminated TB. With } \\
\text { stopping of infliximab, neurological deterioration } \\
\text { occurred with isolation of M.tb in CSF, with no } \\
\text { improvement with corticosteroids. Infliximab } \\
\text { re-initiation led to neurological improvement. }\end{array}$ \\
\hline Molten $^{53}$ & Infliximab & $\begin{array}{l}\text { Case } 1: 10 \mathrm{mg} / \mathrm{kg} \text {, } \\
\text { three doses at } \\
\text { monthly intervals } \\
\text { Case } 2: 5 \mathrm{mg} / \mathrm{kg}, \\
\text { three doses at } 6 \\
\text { week intervals }\end{array}$ & Anti-TNF & $\begin{array}{l}\text { Two cases describing paradoxical worsening } \\
\text { after initiation of TBM treatment, unresponsive to } \\
\text { dexamethasone. In both cases, clinical improvement } \\
\text { occurred following administration of infliximab. }\end{array}$ \\
\hline $\mathrm{Abo}^{54}$ & Infliximab & $\begin{array}{l}5 \mathrm{mg} / \mathrm{kg}, \text { three doses } \\
\text { at weeks } 1,3 \text { and } 7\end{array}$ & Anti-TNF & $\begin{array}{l}\text { Paradoxical worsening (optochiasmatic arachnoiditis, } \\
\text { leading to loss of vision) on starting TB treatment in } \\
\text { a } 7 \text { year old with TBM, despite dexamethasone. } \\
\text { Clinical improvement occurred following infliximab } \\
\text { administration. }\end{array}$ \\
\hline Keeley ${ }^{56}$ & Anakinra & $\begin{array}{l}100 \mathrm{mg} \\
\text { subcutaneously daily }\end{array}$ & $\begin{array}{l}\text { Interleukin-1 } \\
\text { receptor } \\
\text { antagonist }\end{array}$ & $\begin{array}{l}\text { Two cases of steroid dependant neurotuberculosis } \\
\text { (paradoxical worsening when steroids stopping). In } \\
\text { both cases, patients responded to anakinra therapy. }\end{array}$ \\
\hline $\begin{array}{l}\text { A. Gonzalez- } \\
\text { Duarte }\end{array}$ & Cyclophosphamide & $\begin{array}{l}750 \mathrm{mg} / \mathrm{m}^{3} \text { every } \\
3 \text { weeks }\end{array}$ & $\begin{array}{l}\text { Alkylating agent } \\
\text { of nitrogen } \\
\text { mustard type. } 2\end{array}$ & Clinical improvement \\
\hline Celloti $^{57}$ & Cyclophosphamide & $\begin{array}{l}750 \mathrm{mg} / \mathrm{m}^{3} \text { every } \\
3 \text { weeks }\end{array}$ & $\begin{array}{l}\text { Alkylating agent } \\
\text { of nitrogen } \\
\text { mustard type. } 2\end{array}$ & Clinical improvement \\
\hline $\mathrm{Lee}^{72}$ & Adalimumab & $\begin{array}{l}\text { 40mg SC, total } 3 \\
\text { doses every } 2 \text { weeks }\end{array}$ & Anti-TNF & Clinical improvement \\
\hline $\operatorname{Lwin}^{73}$ & Adalimumab & $\begin{array}{l}40 \mathrm{mg} \text { SC, every } 2 \\
\text { weeks for } 3 \text { months }\end{array}$ & Anti-TNF & $\begin{array}{l}\text { Clinical improvement of TBM IRIS refractory to steroid } \\
\text { treatment }\end{array}$ \\
\hline
\end{tabular}

TNF = tumor necrosis factor

atorvastatin led to profound attenuation of $\mathrm{T}$ cell, neutrophil and natural killer cell invasion into the $\mathrm{CNS}$, and reduction in production of pro-inflammatory cytokines (IFN-y and IL-6) and chemokines (CCL5 and CXCL10) ${ }^{74}$. In a double-blind randomised trial involving 36 patients with traumatic brain injury, rosuvastatin given for 10 days in the acute phase of injury significantly reduced TNF- $\alpha$ which correlated with a reduction in disability scores $^{75}$. Other conditions where the role of statins has been explored include Alzheimer's disease ${ }^{76}$, and Parkinson's disease ${ }^{77}$. Further, statins may be associated with reduced risk of tuberculosis ${ }^{78}$. In a TB murine model, adjunctive simvastatin shortened time to culture clearance by 1 month, enhanced bacterial killing, and decreased culture-positive relapse and enhance bacterial killing ${ }^{79-81}$. Clinical trials (NCT03456102, NCT04147286) will investigate the efficacy of statins in pulmonary tuberculosis. Given their potential use as an adjunctive TB therapy, their lipophilic properties allowing good penetration to the CNS, as well as their potential as an anti-inflammatory and neuroprotective agent, statins may have a role as a HDT in TBM; trials to explore this hypothesis are needed.

\section{Glutamate 'grabbing' drugs}

Excessive glutamate and neuro-excitotoxicity are thought to contribute to brain injury and cell death in TBM. In one study, RNA sequencing of whole blood and CSF from children with TBM demonstrated significant enrichment of transcripts associated with neural excitotoxicity predominantly driven by glutamate release, NMDA receptor binding and uptake ${ }^{82}$. This mechanism is thought to contribute to brain injury and 


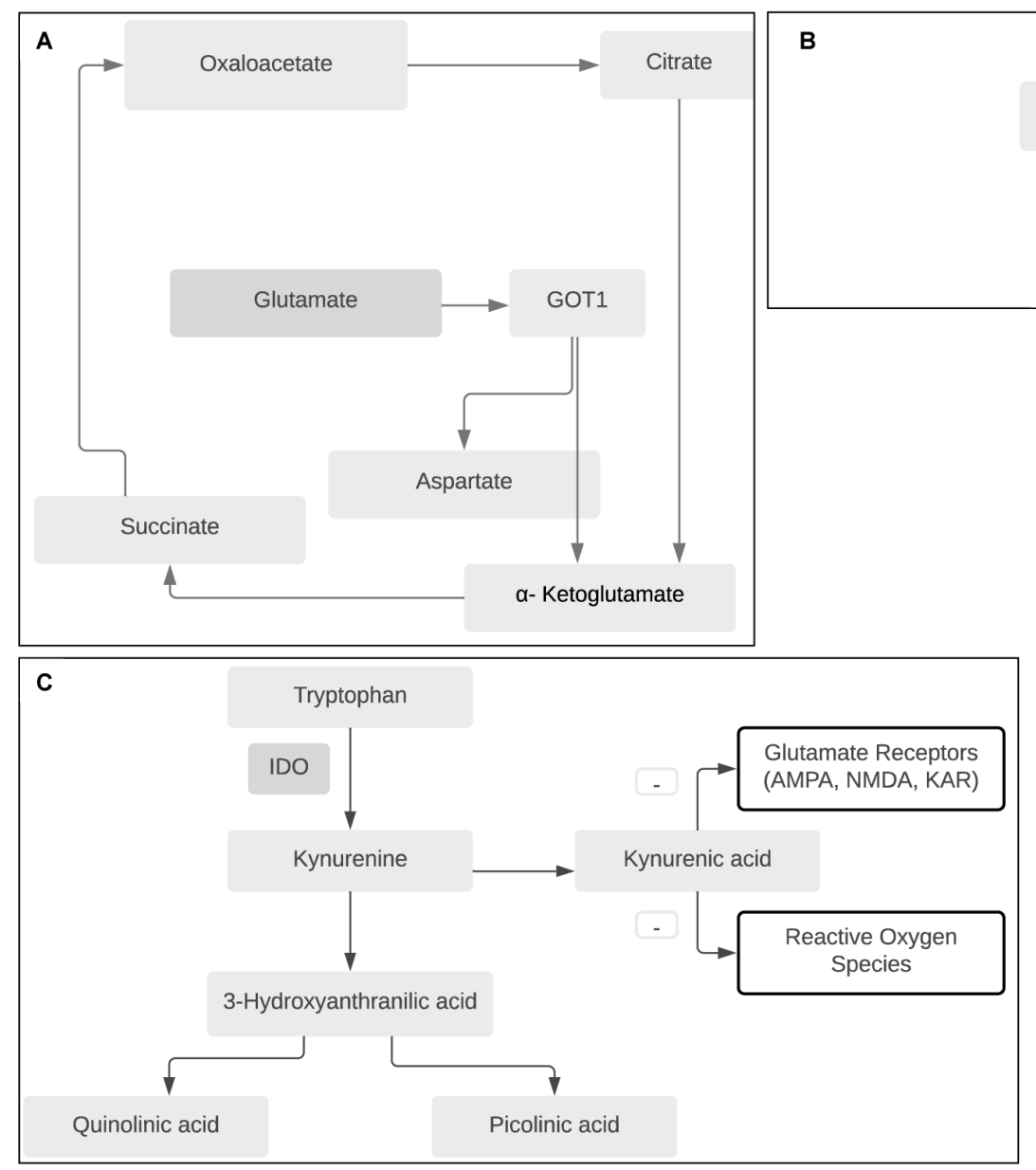

Figure 2. Schematic of relevant biochemical pathways which, if targeted with future host directed therapies, may improve outcomes in TBM. A: Drugs which reduce glutamate 'glutamate grabbers' by increasing breakdown of glutamate (either recombinant glutamic-oxaloacetic transaminase (GOT1), or others that mimic its action) may decrease neuro-excitotoxicity associated with brain injury in TBM. B: Phosphodiesterase inhibitors reduce breakdown of CAMP to 5'AMP leading to increased neuronal survival, immune modulation, and increase in axon plasticity and myelination. C: Interruption of the tryptophan pathway via modulation of Indoleamine 2,3-dioxygenase (IDO) activity may have neuroprotective effect, although more data to understand the role of downstream metabolites particularly the contribution of kyruneic acid in antagonism of glutamate receptors is needed.

cell death in other neurological conditions such as stroke, epilepsy, traumatic brain injury, Alzheimer's and Huntington's disease ${ }^{83,84}$. Therapeutics which aim to reduce glutamate excitotoxicity either by i) modulating the downstream effects of glutamate via NMDA receptor binding or ii) reducing extracellular glutamate (e.g. glutamate 'grabbing') may have a role in the treatment of TBM. In acute stroke, a similar approach was taken however although animal studies were promising, randomised trials in humans assessing efficacy of NMDA antagonists largely failed ${ }^{85-87}$. Therapeutics have been designed to reduce glutamate induced excitotoxicity by lowering blood glutamate concentration thus leading to a larger natural glutamate gradient between the brain and blood thereby facilitating the efflux of extracellular brain glutamate into the blood $^{88}$. In an animal study riboflavin (vitamin $\mathrm{B}_{2}$ ), selected for its ability to interact with Glutamate-Oxaloacetate transaminase (GOT) to significantly reduced blood glutamate levels compared to placebo (Figure $2 \mathrm{~A})^{89}$. In a randomised trial, riboflavin was correlated with improvement of disability when given intravenously in adults with acute stroke ${ }^{89}$. A number of studies have explored the neuroprotective properties of riboflavin including in conditions such as migraine and Parkinson's disease ${ }^{90}$. It is unclear whether drugs such as riboflavin, or others which reduce glutamate neuro-excitotoxicity, have a role as an adjunctive therapy to promote neuroprotection in TBM; however, given the emerging body of evidence which suggest involvement of the glutamate-glutamine pathway, this is a potential area of interest for future studies. 
Tryptophan Pathway Drug Targets

Tryptophan is an essential amino acid which can either be converted to serotonin or oxidized kynurenines via indoleamine 2,3-dioxygenase (IDO1) (Figure 2C). Further oxidization occurs to convert kynurenine to kynurenic acid, which has neuroprotective properties. Prior studies have shown that $M . t b$ induces marked upregulation of IDO-1 expression in both human and murine macrophages in vitro ${ }^{11}$; and that blockade of IDO activity reduces both clinical manifestations of TB as well as microbial and pathological correlates of the human TB syndrome in macaques ${ }^{92}$. In an observational cohort study of TBM, low CSF tryptophan levels were found in those who survived, compared to non-survivors or controls ${ }^{93}$. It is therefore unclear in TBM whether drugs which block IDO-1 such as indoximod, an immunometabolic adjuvant that is current under investigation in cancer therapy ${ }^{94}$, would cause benefit or harm. It is plausible that improved survival seen in those with low CSF tryptophan is due to increased availability of kynurenic acid which has neuroprotective action via glutamate receptors and reactive oxygen species. Further investigation into the influence of tryptophan and its downstream metabolites on pathogenesis in TBM is required in order to establish suitable targets along this pathway for HDTs.

\section{Eicosanoid Modulating Drugs}

Eicosanoids are arachidonic acid derived lipid mediators that trigger pro-and anti-inflammatory responses and include prostaglandins, resolvins, lipoxins, and leukotrienes which serve as signalling molecules, modulating inflammation and cell death in $\mathrm{TB}^{95}$. A delicate balance in eicosanoid levels is crucial for M.tb control and regulating the production of pro-inflammatory cytokines $^{96}$.

Non-steroidal inflammatory drugs (NSAIDs), which exert their effects by inhibiting cyclooxygenase (COX) activity may lead to reduction of excessive inflammation in TBM. As discussed, aspirin, a non-selective COX inhibitor has been investigated in three trials in TBM with variable outcomes ${ }^{27,34,36}$. New generation NSAIDs with more selective inhibition of COX2 may have more favourable safety profiles. Phase 1 trials to assess the safety and bactericidal activity of celecoxib and etoricoxib in healthy volunteers with a view to developing these agents as HDTs for drug sensitive TB are currently underway (NCT02602509; NCT02503839). Although trials to further investigate the role of aspirin in TBM are underway, future research should consider the potential contribution of newer more selective COX2 inhibitors in TBM.

\section{Phosphodiesterase Inhibitors}

Phosphodiesterase inhibitors (PDE-i) are small-molecule inhibitors that reduce inflammation by increasing intracellular cyclic adenosine monophosphate and cyclic guanine monophosphate ${ }^{97}$ (Figure 2B). Phosphodiesterase 4 (PDE-4) inhibitors such as roflumilast have shown to be effective in the treatment of numerous inflammatory conditions including chronic obstructive inflammatory disease ${ }^{98}$. PDE-4 is expressed within the cortex and hippocampus and animal models suggest that inhibition of PDE-4 may have a beneficial role in CNS conditions where inflammation plays a role in pathogenesis ${ }^{99-103}$. In animal models of pulmonary TB, inhibition of PDE-3 (cilostazol), PDE-4 (roflumilast) and PDE-5 (sildenafil) have all increased bacterial clearance and reduced pro-inflammatory cytokines which contributed to a reduction in neutrophil infiltration and lung pathology ${ }^{104-107}$. The role of phosphodiesterase inhibitors has not been studied in TBM but the properties above make them intriguing candidates for adjunctive therapy in TBM.

\section{Antiretroviral Therapy}

Although not an HDT per se, the decision as to when antiretroviral therapy is started must consider the potential immunopathogenic complications as well as the benefit in preventing further opportunistic infection. Guidelines vary slightly regarding the timing of initiation of ART relative to initiation of anti-TB chemotherapy in those co-infected with TB and HIV. The 2010 World Health Organisation (WHO) ART guidelines recommend initiating ART within 8 weeks of anti-TB chemotherapy in all HIV-TB co-infected patients regardless of CD4 count ${ }^{108}$. The U.S. National Institutes of Health HIV guidelines recommend starting ART within 2 weeks of anti-TB chemotherapy for HIV-TB co-infected patients with CD4 cell counts $<50$ cells/ $\mu \mathrm{L}$ and within 8 weeks for CD4 counts $>50$ cells $/ \mu \mathrm{L}^{109}$. In TBM there are unique considerations given the infection surrounds crucial structures (the brain and spinal cord) with a very limited ability to expand within the skull and spinal canal should excess inflammation occur. Inflammation occurring following the initiation of HIV therapy is known as immune reconstitution inflammatory syndrome (IRIS), which in the context of TBM is associated is frequent (up to $40 \%$ ) and associated with high mortality $(30 \%)^{110,111}$.

In a randomised trial of testing immediate HIV therapy initiation (at time of initiating TB treatment) vs delayed (after 2 months) in TBM, immediate therapy was associated with significantly more grade 4 adverse events $(n=102)$ than delayed HIV therapy $(n=87 ; p=.04)$. This trial informed current consensus that ART initiation should be delayed by between 4-8 weeks after starting TBM therapy ${ }^{112}$. This approach hopes to strike a balance between the beneficial effects of ART (immune reconstitution, control of HIV, prevention of other opportunistic infections) and the potential harms of TB-IRIS.

\section{Variable Host Responses and a Personalized Approach}

Host immune response to M.tb in TBM is vital; although excessive inflammation leads to neurological damage. Polymorphisms in genes involved in immune response or signaling pathways can influence host inflammatory response, or susceptibility to $\mathrm{TBM}^{113}$.

A previous study in the zebrafish model showed that the leukotriene A4 hydrolase $(L T A 4 H)$ gene influenced the balance 
of pro and anti-inflammatory eicosanoids in response to $M$ tuberculosis infection ${ }^{114}$. LTA4H catalyzes the final step in pro-inflammatory leukotriene B4 (LTB4) synthesis ${ }^{114}$, with LTB4 effects usually balanced by anti-inflammatory lipoxin A4 (LXA4), the two together ensuring an appropriate response to $M$. tuberculosis without excessive tissue damage ${ }^{115}$. A single nucleotide polymorphism (SNP) (rs17525495) in the promoter region of the $L A T 4 H$ gene alters gene expression, and LTB4 LXA4 balance; low (CC) and high (TT) inflammatory states result from $L T A 4 H$ allele homozygosity whereas an intermediate (CT) inflammatory state results from allele heterozygosity ${ }^{114}$. Both TT and CC inflammatory states were associated with increased death in a retrospective study of adults with $\mathrm{TBM}^{116}$. In this retrospective study adjunctive dexamethasone was associated with improved survival in the high inflammatory TT group, with the effect of dexamethasone unclear in the CC and CT groups ${ }^{116}$. In a subsequent study of 764 Vietnamese adults, ten CSF cytokines were measured of: TNF- $\alpha$, IFN- $\gamma$, IL-1 $\beta$, IL-2, IL4, IL-5, IL-6, IL-10, IL-12, IL-13 ${ }^{14}$. In HIV-uninfected adults with TBM, pro-inflammatory IL-1 $\beta$, IL-2, and IL-6 (but not TNF- $\alpha$ ) were significantly associated with $L T A 4 H$ genotype; low concentrations in CC genotype, intermediate concentrations in CT genotype, and high concentrations in TT genotype ${ }^{14}$. In HIV co-infected individuals with TBM, LTA4H genotype did not appear to influence survival, response to dexamethasone, or CSF cytokine profile $^{14}$. Additionally $L T A 4 H$ genotype did not influence survival in a study of HIV-uninfected Indonesian adults with TBM, all of whom received corticosteroids ${ }^{117}$. A LTA4H genotype stratified approach to adjunctive corticosteroid therapy in TBM is now being assessed in an ongoing randomized placebo-controlled $L T A 4 H$ genotype stratified non-inferiority trial of HIV uninfected adults with TBM in Vietnam $(\mathrm{NCT} 03100786)^{118}$. If benefits of adjunctive corticosteroids as a host directed therapy are shown to be limited to one or more LTA4H genotypes, this paves the way for personalized corticosteroid therapy in TBM. Such benefit related to $L T A 4 H$ genotype may lead to innovation and development of affordable point of care tests, to enable implementation of $L T A 4 H$ genotype testing into patient management.

Where variable host responses to M. tuberculosis increase intracerebral inflammation, or genetic polymorphisms lead to overexpression of a specific molecule or target, targeted personalized therapies may be beneficial. In a study of tryptophan genome wide SNP data we identified 11 quantitative trait loci associated with CSF tryptophan concentrations, and found that these quantitative trait loci were predictive of patient survival ${ }^{19}$. A SNP (rs17842268) in CD43, a surface glycoprotein, has been associated with more severe presentation, and decreased survival, in $\mathrm{TBM}^{119}$. Why SNPs in CD43 affect $M$ tuberculosis susceptibility is uncertain, but CD43 has a role in regulating proinflammatory cytokines ${ }^{119}$, and theoretically anti-inflammatory therapies may be beneficial in such patients., evidence that patients with a dysregulated host immune response benefit from more, or different, host directed therapies is lacking.

\section{Conclusions and Key Areas for Future Research}

Host directed therapies are an evolving area of TBM research. We know that the inflammatory response in TBM contributes to poor outcomes. Further, we know that dexamethasone reduces death from TBM. What is unknown is how the drug works, who might benefit most from dexamethasone or whether other therapies should be given in addition to dexamethasone or in place of it in some scenarios. There may also be scenarios where dexamethasone is harmful. Important questions regarding the exact role of thalidomide and aspirin also remain. While in the case of the former, a narrow context in which the drug might be useful is becoming clearer, in the latter the optimal and safe dose of aspirin considering its antiplatelet and anti-inflammatory properties, is uncertain. Although the use of immunomodulatory therapies have been reported sporadically, often where corticosteroid treatments have failed, no clinical trials have been conducted to systematically assess their safety profile and efficacy.

Drug discovery depends on accurately identifying molecular targets which play crucial roles in disease biology, and which are amenable to modulation via biologics or small molecule drug therapeutics. In diseases with high global incidences such diabetes or hypertension, large scale data repositories are beginning to provide genetic insights to inform drug discovery and therefore change the direction of and speed at which novel and repurposed therapeutics become available ${ }^{120}$. In TBM we must work towards establishing similar repositories through international collaboration. However, the relatively low global incidence of the disease, and the challenging environments in which TBM most commonly occurs will make this a lengthy endeavour.

In the near future, we can focus on better understanding of key pathogenic processes underpinning inflammation and brain injury. For example, further understanding of the role and interaction of glutamate and tryptophan in brain injury may uncover targets for which existing drugs can be repurposed and novel therapeutics developed. The rational design of animal models to help inform which of these might deserve clinical trials in TBM is also key; although the rabbit model of TBM has been in use since the early $1900 \mathrm{~s}^{121}$, further research is required to establish whether a more refined or alternative model could better recapitulate human disease. Genomic research to identify variation in host response will allow further refinement of therapeutic approaches based on factors at the individual patient and population level. While studies of LTA4H genotype have led the way in this area of TBM research, focus must now widen to include other pathways that are likely to vary between hosts. As we move forward with host-directed therapies for TBM we must remain cognisant of the characteristics of the hosts whose responses we are attempting to change. Whether these changes are obvious (e.g. HIV infection) or more opaque (e.g. unknown genetic polymorphisms) they must be considered with trial design so that we can understand as fully as possible, the role of these therapies in improving outcomes in TBM. 
1. Thwaites GE, Nguyen DB, Nguyen HD, et al.: Dexamethasone for the treatment of tuberculous meningitis in adolescents and adults. $N$ Engl $\rfloor$ Med. 2004; 351(17): 1741-1751.

PubMed Abstract | Publisher Full Text

2. Schoeman JF, Van Zyl LE, Laubscher JA, et al.: Effect of corticosteroids on intracranial pressure, computed tomographic findings, and clinical outcome in young children with tuberculous meningitis. Pediatrics. 1997; 99(2): 226-231.

PubMed Abstract | Publisher Full Text

3. Prasad $\mathrm{K}$, Singh $\mathrm{MB}$, Ryan $\mathrm{H}$ : Corticosteroids for managing tuberculous meningitis. Cochrane Database Syst Rev. 2016; 4(4): CD002244. PubMed Abstract | Publisher Full Text | Free Full Text

4. Torok ME, Nguyen DB, Tran TH, et al.: Dexamethasone and long-term outcome of tuberculous meningitis in Vietnamese adults and adolescents. PloS One. 2011; 6(12): e27821.

PubMed Abstract | Publisher Full Text | Free Full Text

5. Abraham SM, Lawrence T, Kleiman A, et al.: Antiinflammatory effects of dexamethasone are partly dependent on induction of dual specificity phosphatase 1. J Exp Med. 2006; 203(8): 1883-1889. PubMed Abstract | Publisher Full Text | Free Full Text

6. Meintjes G, Scriven J, Marais S: Management of the immune reconstitution inflammatory syndrome. Curr HIV/AIDS Rep. 2012; 9(3): 238-250. PubMed Abstract | Publisher Full Text

7. Newton R: Molecular mechanisms of glucocorticoid action: what is important? Thorax. 2000; 55(7): 603-613.

PubMed Abstract | Publisher Full Text | Free Full Text

8. Rhen T, Cidlowski JA: Antiinflammatory action of glucocorticoids--new mechanisms for old drugs. N Eng J Med. 2005; 353(16): 1711-1723. PubMed Abstract | Publisher Full Text

9. Adcock IM: Glucocorticoid-regulated transcription factors. Pulm Pharmacol Ther. 2001; 14(3): 211-219. PubMed Abstract | Publisher Full Text

10. Lee HM, Kang J, Lee SJ, et al.: Microglial activation of the NLRP3 inflammasome by the priming signals derived from macrophages infected with mycobacteria. Glia. 2013; 61(3): 441-452. PubMed Abstract | Publisher Full Text

11. Marais S, Lai RPJ, Wilkinson KA, et al.: Inflammasome Activation Underlying Central Nervous System Deterioration in HIV-Associated Tuberculosis. J Infect Dis. 2017; 215(5): 677-686. PubMed Abstract | Publisher Full Text | Free Full Text

12. Misra UK, Kalita J, Srivastava R, et al.: A study of cytokines in tuberculous meningitis: clinical and MRI correlation. Neurosci Lett. 2010; 483(1): 6-10. PubMed Abstract | Publisher Full Text

13. Donald PR, Van Toorn R: Use of corticosteroids in tuberculous meningitis. Lancet. 2016; 387(10038): 2585-2587.

PubMed Abstract | Publisher Full Text

14. Thuong NTT, Heemskerk D, Tram TTB, et al.: Leukotriene A4 Hydrolase Genotype and HIV Infection Influence Intracerebral Inflammation and Survival From Tuberculous Meningitis. J Infect Dis. 2017; 215(7): 1020-1028. PubMed Abstract | Publisher Full Text | Free Full Text

15. Simmons $\mathrm{CP}$, Thwaites GE, Quyen NT, et al:: The clinical benefit of adjunctive dexamethasone in tuberculous meningitis is not associated with measurable attenuation of peripheral or local immune responses. Immunol. 2005; 175(1): 579-590. PubMed Abstract | Publisher Full Text

16. Green JA, Tran CT, Farrar JJ, et al.: Dexamethasone, cerebrospinal fluid matrix metalloproteinase concentrations and clinical outcomes in tuberculous meningitis. PLoS One. 2009; 4(9): e7277.

PubMed Abstract | Publisher Full Text | Free Full Text

17. Thwaites G, Fisher M, Hemingway $C$, et al.: British Infection Society guidelines for the diagnosis and treatment of tuberculosis of the central nervous system in adults and children. J Infect. 2009; 59(3): 167-187.

PubMed Abstract | Publisher Full Text

18. Donovan J, Figaji A, Imran D, et al.: The neurocritical care of tuberculous meningitis. Lancet Neurol. 2019; 18(8): 771-783. PubMed Abstract | Publisher Full Text

19. Donovan J, Phu NH, Mai NTH, et al.: Adjunctive dexamethasone for the treatment of HIV-infected adults with tuberculous meningitis (ACT HIV): Study protocol for a randomised controlled trial [version 2; peer review: 1 approved, 2 approved with reservations]. Wellcome Open Res. 2018; 3: 31. PubMed Abstract | Publisher Full Text | Free Full Text

20. Thuong NTT, Thwaites GE: Treatment-Associated Inflammatory Deterioration in Tuberculous Meningitis: Unpicking the Paradox. J Infect Dis. 2017; 215(5): 665-667.

PubMed Abstract | Publisher Full Text | Free Full Text

21. Marais S, Meintjes G, Pepper DJ, et al.: Frequency, severity, and prediction of tuberculous meningitis immune reconstitution inflammatory syndrome. Clin Infect Dis. 2013; 56(3): 450-460.

PubMed Abstract | Publisher Full Text | Free Full Text
22. Meintjes G, Stek C, Blumenthal L, et al.: Prednisone for the Prevention of Paradoxical Tuberculosis-Associated IRIS. N Eng J Med. 2018; 379(20): 1915-1925.

PubMed Abstract | Publisher Full Text

23. Girgis NI, Farid Z, Kilpatrick ME, et al.: Dexamethasone adjunctive treatmen for tuberculous meningitis. Pediatr Infect Dis J. 1991; 10(3): 179-183. PubMed Abstract | Publisher Full Text

24. O'Toole RD, Thornton GF, Mukherjee MK, et al:: Dexamethasone in tuberculous meningitis. Relationship of cerebrospinal fluid effects to therapeutic efficacy. Ann Intern Med. 1969; 70(1): 39-48. PubMed Abstract | Publisher Full Text

25. Kumarvelu S, Prasad K, Khosla A, et al.: Randomized controlled trial of dexamethasone in tuberculous meningitis. Tuber Lung Dis. 1994; 75(3): 203-207.

PubMed Abstract | Publisher Full Text

26. Shah I, Meshram L: High dose versus low dose steroids in children with tuberculous meningitis. J Clin Neurosci. 2014; 21(5): 761-764.

PubMed Abstract | Publisher Full Text

27. Mai NT, Dobbs N, Phu NH, et al.: A randomised double blind placebo controlled phase 2 trial of adjunctive aspirin for tuberculous meningitis in HIV-uninfected adults. elife. 2018; 7: e33478.

PubMed Abstract | Publisher Full Text | Free Full Text

28. Wasay $\mathrm{M}$, Khan $\mathrm{M}$, Farooq $\mathrm{S}$, et al.: Frequency and Impact of Cerebral Infarctions in Patients With Tuberculous Meningitis. Stroke. 2018; 49(10): 2288-2293.

PubMed Abstract | Publisher Full Text

29. Wen L, Li M, Xu T, et al.: Clinical features, outcomes and prognostic factors of tuberculous meningitis in adults worldwide: systematic review and meta-analysis. J Neurol. 2019; 266(12): 3009-3021. PubMed Abstract | Publisher Full Text

30. Sharma S, Goyal MK, Sharma K, et al: Cytokines do play a role in pathogenesis of tuberculous meningitis: A prospective study from a tertiary care center in India. J Neurol Sci. 2017; 379: 131-136. PubMed Abstract | Publisher Full Text

31. Schoeman J, Mansvelt $E$, Springer $P$, et al.: Coagulant and fibrinolytic status in tuberculous meningitis. Pediatr Infect Dis J. 2007; 26(5): 428-431. PubMed Abstract | Publisher Full Text

32. Lammie GA, Hewlett RH, Schoeman JF, et al.: Tuberculous cerebrovascular disease: a review. J Infect. 2009; 59(3): 156-166.

PubMed Abstract | Publisher Full Text

33. Davis AG, Rohlwink UK, Proust A, et al.: The pathogenesis of tuberculous meningitis. J Leukoc Biol. 2019; 105(2): 267-280. PubMed Abstract | Publisher Full Text | Free Full Text

34. Misra UK, Kalita J, Nair PP: Role of aspirin in tuberculous meningitis: a randomized open label placebo controlled trial. J Neurol Sci. 2010; 293(1-2): 12-17.

PubMed Abstract | Publisher Full Text

35. Misra UK, Kalita J, Sagar B, et al.: Does adjunctive corticosteroid and aspirin therapy improve the outcome of tuberculous meningitis? Neurol India. 2018; 66(6): 1672-1677. PubMed Abstract | Publisher Full Tex

36. Schoeman JF, van Rensburg AJ, Laubscher JA, et al:: The role of aspirin in childhood tuberculous meningitis. J Child Neurol. 2011; 26(8): 956-962. PubMed Abstract | Publisher Full Text

37. Schoeman JF, Springer P, Ravenscroft A, et al.: Adjunctive thalidomide therapy of childhood tuberculous meningitis: possible anti-inflammatory role. J Child Neurol. 2000; 15(8): 497-503. PubMed Abstract | Publisher Full Text

38. Schoeman JF, Springer P, van Rensburg AJ, et al.: Adjunctive thalidomide therapy for childhood tuberculous meningitis: results of a randomized study. J Child Neurol. 2004; 19(4): 250-257. PubMed Abstract | Publisher Full Text

39. Verma R, Mahapatro S, Kumar A, et al.: Platelet dysfunction and coagulation assessment in patients of tuberculous meningitis. Neurol Sci. 2020; 41(8): 2103-2110.

PubMed Abstract | Publisher Full Text

40. Kroesen VM, Rodriguez-Martinez P, Garcia E, et al.: A Beneficial Effect of LowDose Aspirin in a Murine Model of Active Tuberculosis. Front Immunol. 2018; 9: 798.

PubMed Abstract | Publisher Full Text | Free Full Text

41. P.H.E: Tuberculosis in England: 2018. Public Health England, London, 2018.

42. Vane JR, Botting RM: The mechanism of action of aspirin. Thromb Res. 2003; 110(5-6): 255-258. PubMed Abstract | Publisher Full Text

43. Dian S, Hermawan R, van Laarhoven A, et al.: Brain MRI findings in relation to clinical characteristics and outcome of tuberculous meningitis. PLOS One. 2020; 15(11): e0241974. PubMed Abstract | Publisher Full Text | Free Full Text

44. Haslett PA, Corral LG, Albert M, et al.: Thalidomide costimulates primary 
human T lymphocytes, preferentially inducing proliferation, cytokine production, and cytotoxic responses in the CD8+ subset.J Exp Med. 1998; 187(11): 1885-1892.

PubMed Abstract | Publisher Full Text | Free Full Text

45. Tsenova L, Sokol K, Freedman VH, et al.: A combination of thalidomide plus antibiotics protects rabbits from mycobacterial meningitis-associated death. J Infect Dis. 1998; 177(6): 1563-1572.

PubMed Abstract | Publisher Full Text

46. Schoeman JF, Fieggen $\mathrm{G}$, Seller $\mathrm{N}$, et al.: Intractable intracranial tuberculous infection responsive to thalidomide: report of four cases. J Child Neurol. 2006; 21(4): 301-308.

PubMed Abstract | Publisher Full Text

47. van Toorn R, du Plessis AM, Schaaf HS, et al.: Clinicoradiologic response of neurologic tuberculous mass lesions in children treated with thalidomide. Pediatr Infect Dis J. 2015; 34(2): 214-218.

PubMed Abstract | Publisher Full Text

48. Roberts MT, Mendelson M, Meyer $\mathrm{P}$, et al.: The use of thalidomide in the treatment of intracranial tuberculomas in adults: two case reports. J Infect. 2003; 47(3): 251-255.

PubMed Abstract | Publisher Full Text

49. Schoeman JF, Andronikou S, Stefan DC, et al.: Tuberculous meningitis-related optic neuritis: recovery of vision with thalidomide in $\mathbf{4}$ consecutive cases. J Child Neurol. 2010; 25(7): 822-828.

PubMed Abstract | Publisher Full Text

50. Ottum PA, Arellano G, Reyes LI, et al.: Opposing Roles of Interferon Gamma on Cells of the Central Nervous System in Autoimmune Neuroinflammation. Front Immunol. 2015; 6: 539 PubMed Abstract | Publisher Full Text | Free Full Text

51. Blackmore TK, Manning L, Taylor WJ, et al.: Therapeutic use of infliximab in tuberculosis to control severe paradoxical reaction of the brain and lymph nodes. Clin Infect Dis. 2008; 47(10): e83-85.

PubMed Abstract | Publisher Full Text

52. Jorge JH, Graciela C, Pablo AP, et al.: A life-threatening central nervous system-tuberculosis inflammatory reaction nonresponsive to corticosteroids and successfully controlled by infliximab in a young patient with a variant of juvenile idiopathic arthritis. J Clin Rheumatol. 2012 18(4): 189-191.

PubMed Abstract | Publisher Full Text

53. Molton JS, Huggan PJ, Archuleta S: Infliximab therapy in two cases of severe neurotuberculosis paradoxical reaction. Med J Aust. 2015; 202(3): 156-157. PubMed Abstract | Publisher Full Text

54. Abo YN, Curtis N, Butters C, et al.: Successful Treatment of a Severe VisionThreatening Paradoxical Tuberculous Reaction with Infliximab: First Pediatric Use. Pediatr Infect Dis J. 2020; 39(4): e42-e45. PubMed Abstract | Publisher Full Text

55. Harris J, Keane J: How tumour necrosis factor blockers interfere with tuberculosis immunity. Clin Exp Immunol. 2010; 161(1): 1-9. PubMed Abstract | Publisher Full Text | Free Full Tex

56. Keeley AJ, Parkash V, Tunbridge A, et al.: Anakinra in the treatment of protracted paradoxical inflammatory reactions in HIV-associated tuberculosis in the United Kingdom: a report of two cases. Int J STD AIDS. 2020; 31(8): 808-812.

PubMed Abstract | Publisher Full Text | Free Full Text

57. Celotti A, Vianello F, Sattin A, et al.: Cyclophosphamide immunomodulation of TB-associated cerebral vasculitis. Infect Dis (Lond). 2018; 50(10): 779-782. PubMed Abstract | Publisher Full Text

58. Gonzalez-Duarte A, Higuera-Calleja J, Flores F, et al.: Cyclophosphamide treatment for unrelenting CNS vasculitis secondary to tuberculous meningitis. Neurology. 2012; 78(16): 1277-1278.

PubMed Abstract | Publisher Full Text

59. Kata D, Földesi I, Feher LZ, et al.: Rosuvastatin enhances anti-inflammatory and inhibits pro-inflammatory functions in cultured microglial cells. Neuroscience. 2016; 314: 47-63.

PubMed Abstract | Publisher Full Text

60. Churchward MA, Todd KG: Statin treatment affects cytokine release and phagocytic activity in primary cultured microglia through two separable mechanisms. Mol Brain. 2014; 7: 85

PubMed Abstract | Publisher Full Text | Free Full Text

61. Cordle A, Landreth G: 3-Hydroxy-3-methylglutaryl-coenzyme A reductase inhibitors attenuate beta-amyloid-induced microglial inflammatory responses. J Neurosci. 2005; 25(2): 299-307.

PubMed Abstract | Publisher Full Text | Free Full Text

62. McFarland AJ, Davey AK, McDermott CM, et al.: Differences in statin associated neuroprotection corresponds with either decreased production of IL-1 $\beta$ or TNF- $\alpha$ in an in vitro model of neuroinflammation-induced neurodegeneration. Toxicol Appl Pharmacol. 2018; 344: 56-73. PubMed Abstract | Publisher Full Text

63. Waiczies S, Bendix I, Zipp F: Geranylgeranylation but not GTP-loading of Rho GTPases determines T cell function. Sci Signal. 2008; 1(12): pt3. PubMed Abstract | Publisher Full Text

64. Weitz-Schmidt G, Welzenbach K, Brinkmann V, et al.: Statins selectively inhibit leukocyte function antigen-1 by binding to a novel regulatory integrin site. Nat Med. 2001; 7(6): 687-692.

PubMed Abstract | Publisher Full Text
65. Bösel J, Gandor F, Harms C, et al.: Neuroprotective effects of atorvastatin against glutamate-induced excitotoxicity in primary cortical neurones. I Neurochem. 2005; 92(6): 1386-1398.

PubMed Abstract | Publisher Full Text

66. Ponce J, de la Ossa NP, Hurtado O, et al.: Simvastatin reduces the association of NMDA receptors to lipid rafts: a cholesterol-mediated effect in neuroprotection. Stroke. 2008; 39(4): 1269-1275.

PubMed Abstract | Publisher Full Text

67. Michikawa M, Yanagisawa K: Inhibition of cholesterol production but not of nonsterol isoprenoid products induces neuronal cell death. J Neurochem. 1999; 72(6): 2278-2285.

PubMed Abstract | Publisher Full Text

68. Tanaka T, Tatsuno I, Uchida D, et al.: Geranylgeranyl-pyrophosphate, an isoprenoid of mevalonate cascade, is a critical compound for rat primary cultured cortical neurons to protect the cell death induced by 3-hydroxy-3methylglutaryl-CoA reductase inhibition. J Neurosci. 2000; 20(8): 2852-2859. PubMed Abstract | Publisher Full Text | Free Full Text

69. Schulz JG, Bösel J, Stoeckel M, et al.: HMG-CoA reductase inhibition causes neurite loss by interfering with geranylgeranylpyrophosphate synthesis. J Neurochem. 2004; 89(1): 24-32.

PubMed Abstract | Publisher Full Text

70. Youssef S, Stüve O, Patarroyo JC, et al.: The HMG-CoA reductase inhibitor, atorvastatin, promotes a Th2 bias and reverses paralysis in central nervous system autoimmune disease. Nature. 2002; 420(6911): 78-84. PubMed Abstract | Publisher Full Text

71. Chataway J, Schuerer N, Alsanousi A, et al:: Effect of high-dose simvastatin on brain atrophy and disability in secondary progressive multiple sclerosis (MS-STAT): a randomised, placebo-controlled, phase 2 trial. Lancet. 2014; 383(9936): 2213-2221. PubMed Abstract | Publisher Full Text

72. Lee HS, Lee $\mathrm{Y}$, Lee SO, et al.: Adalimumab treatment may replace or enhance the activity of steroids in steroid-refractory tuberculous meningitis. J Infect Chemother. 2012; 18(4): 555-557.

PubMed Abstract | Publisher Full Text

73. Lwin N, Boyle M, Davis JS: Adalimumab for Corticosteroid and InfliximabResistant Immune Reconstitution Inflammatory Syndrome in the Setting of TB/HIV Coinfection. Open Forum Infect Dis. 2018; 5(2): ofy027. PubMed Abstract | Publisher Full Text | Free Full Text

74. $\mathrm{Xu} \mathrm{X,} \mathrm{Gao} \mathrm{W,} \mathrm{Cheng} \mathrm{S,} \mathrm{et} \mathrm{al.:} \mathrm{Anti-inflammatory} \mathrm{and} \mathrm{immunomodulatory}$ mechanisms of atorvastatin in a murine model of traumatic brain injury. J Neuroinflammation. 2017; 14(1): 167.

PubMed Abstract | Publisher Full Text | Free Full Text

75. Sánchez-Aguilar M, Tapia-Pérez JH, Sánchez-Rodríguez JJ, et al.: Effect of rosuvastatin on cytokines after traumatic head injury. J Neurosurg. 2013 118(3): 669-675.

PubMed Abstract | Publisher Full Text

76. Jick H, Zornberg GL, Jick SS, et al.: Statins and the risk of dementia. Lancet 2000; 356(9242): 1627-1631.

PubMed Abstract | Publisher Full Text

77. Yan J, Qiao L, Tian J, et al.: Effect of statins on Parkinson's disease: A systematic review and meta-analysis. Medicine (Baltimore). 2019; 98(12): e14852.

PubMed Abstract | Publisher Full Text | Free Full Text

78. Lai CC, Lee MTG, Lee SH, et al.: Statin treatment is associated with a decreased risk of active tuberculosis: an analysis of a nationally representative cohort. Thorax. 2016; 71(7): 646-651.

PubMed Abstract | Publisher Full Text

79. Dutta NK, Bruiners N, Pinn ML, et al.: Statin adjunctive therapy shortens the duration of TB treatment in mice. J Antimicrob Chemother. 2016; 71(6): 1570-1577.

PubMed Abstract | Publisher Full Text | Free Full Text

80. Skerry C, Pinn ML, Bruiners $N$, et al.: Simvastatin increases the in vivo activity of the first-line tuberculosis regimen. J Antimicrob Chemother. 2014; 69(9): 2453-2457.

PubMed Abstract | Publisher Full Text | Free Full Text

81. Parihar SP, Guler R, Khutlang R, et al.: Statin therapy reduces the mycobacterium tuberculosis burden in human macrophages and in mice by enhancing autophagy and phagosome maturation. J Infect Dis. 2014; 209(5): 754-763.

PubMed Abstract | Publisher Full Text

82. Rohlwink UK, Figaji A, Wilkinson KA, et al.: Tuberculous meningitis in children is characterized by compartmentalized immune responses and neural excitotoxicity. Nat Commun. 2019; 10(1): 3767

PubMed Abstract | Publisher Full Text | Free Full Text

83. Meldrum BS: Glutamate as a neurotransmitter in the brain: review of physiology and pathology. J Nutr. 2000; 130(4S Suppl): 1007S-1015S. PubMed Abstract | Publisher Full Text

84. Wang R, Reddy PH: Role of Glutamate and NMDA Receptors in Alzheimer's Disease. J Alzheimers Dis. 2017; 57(4): 1041-1048.

PubMed Abstract | Publisher Full Text | Free Full Text

85. Jia M, Njapo SAN, Rastogi $\mathrm{V}$, et al.: Taming glutamate excitotoxicity: strategic pathway modulation for neuroprotection. CNS Drugs. 2015; 29(2): 153-162. PubMed Abstract | Publisher Full Text 
86. Kalia LV, Kalia SK, Salter MW: NMDA receptors in clinical neurology: excitatory times ahead. Lancet Neurol. 2008; 7(8): 742-755. PubMed Abstract | Publisher Full Text | Free Full Text

87. Grupke $\mathrm{S}$, Hall J, Dobbs M, et al.: Understanding history, and not repeating it. Neuroprotection for acute ischemic stroke: from review to preview. Clin Neurol Neurosurg. 2015; 129: 1-9. PubMed Abstract | Publisher Full Text

88. Castillo J, Loza MI, Mirelman D, et al.: A novel mechanism of neuroprotection: Blood glutamate grabber. J Cereb Blood Flow Metab. 2016; 36(2): 292-301. PubMed Abstract | Publisher Full Text | Free Full Text

89. da Silva-Candal A, Perez-Diaz A, Santamaria M, et al.: Clinical validation of blood/brain glutamate grabbing in acute ischemic stroke. Ann Neurol. 2018; 84(2): 260-273.

PubMed Abstract | Publisher Full Text

90. Marashly ET, Bohlega SA: Riboflavin Has Neuroprotective Potential: Focus on Parkinson's Disease and Migraine. Front Neurol. 2017; 8: 333. PubMed Abstract | Publisher Full Text | Free Full Text

91. Blumenthal A, Nagalingam $\mathrm{G}, \mathrm{Huch} \mathrm{JH}$, et al:: $\boldsymbol{M}$. tuberculosis induces potent activation of IDO-1, but this is not essential for the immunological contro of infection. PLoS One. 2012; 7(5): e37314. PubMed Abstract | Publisher Full Text | Free Full Text

92. Gautam US, Foreman TW, Bucsan AN, et al.: In vivo inhibition of tryptophan catabolism reorganizes the tuberculoma and augments immune-mediated control of Mycobacterium tuberculosis. Proc Natl Acad Sci U S A. 2018; 115(1): E62-E71.

PubMed Abstract | Publisher Full Text | Free Full Text

93. van Laarhoven A, Dian S, Aguirre-Gamboa R, et al.: Cerebral tryptophan metabolism and outcome of tuberculous meningitis: an observational cohort study. Lancet Infect Dis. 2018; 18(5): 526-535. PubMed Abstract | Publisher Full Text

94. Fox E, Oliver T, Rowe M, et al.: Indoximod: An Immunometabolic Adjuvant That Empowers T Cell Activity in Cancer. Front Oncol. 2018; 8: 370. PubMed Abstract | Publisher Full Text | Free Full Text

95. Ricciotti E, FitzGerald GA: Prostaglandins and inflammation. Arterioscler Thromb Vasc Biol. 2011; 31(5): 986-1000.

PubMed Abstract | Publisher Full Text | Free Full Text

96. Young C, Walzl G, Du Plessis N: Therapeutic host-directed strategies to improve outcome in tuberculosis. Mucosal Immunol. 2020; 13(2): 190-204. PubMed Abstract | Publisher Full Text | Free Full Text

97. Page $\mathrm{CP}$, Spina $\mathrm{D}$ : Phosphodiesterase inhibitors in the treatment of inflammatory diseases. Handb Exp Pharmacol. 2011; (204): 391-414. PubMed Abstract | Publisher Full Text

98. Calverley PM, Rabe KF, Goehring UM, et al:: Roflumilast in symptomatic chronic obstructive pulmonary disease: two randomised clinical trials. Lancet. 2009; 374(9691): 685-694.

PubMed Abstract | Publisher Full Text

99. Schaal SM, Garg MS, Ghosh M, et al.: The therapeutic profile of rolipram, PDE target and mechanism of action as a neuroprotectant following spinal cord injury. PLoS One. 2012; 7(9): e43634. PubMed Abstract | Publisher Full Text | Free Full Text

100. Atkins CM, Oliva AA Jr, Alonso OF, et al.: Modulation of the cAMP signaling pathway after traumatic brain injury. Exp Neurol. 2007; 208(1): 145-158. PubMed Abstract | Publisher Full Text | Free Full Text

101. Gong B, Vitolo OV, Trinchese F, et al.: Persistent improvement in synaptic and cognitive functions in an Alzheimer mouse model after rolipram treatment. J Clin Invest. 2004; 114(11): 1624-1634. PubMed Abstract | Publisher Full Text | Free Full Text

102. Gonzalez-Garcia C, Bravo B, Ballester A, et al.: Comparative assessment of PDE 4 and 7 inhibitors as therapeutic agents in experimental autoimmune encephalomyelitis. Br J Pharmacol. 2013; 170(3): 602-613. PubMed Abstract | Publisher Full Text | Free Full Text

103. Wu Q, Qi L, Li H, et al.: Roflumilast Reduces Cerebral Inflammation in a Rat Model of Experimental Subarachnoid Hemorrhage. Inflammation. 2017; 40(4): 1245-1253.

PubMed Abstract | Publisher Full Text | Free Full Text

104. Subbian S, Tsenova L, O'Brien P, et al.: Phosphodiesterase-4 inhibition combined with isoniazid treatment of rabbits with pulmonary tuberculosis reduces macrophage activation and lung pathology. Am J Pathol. 2011; 179(1): 289-301

PubMed Abstract | Publisher Full Text | Free Full Text

105. Maiga MC, Ahidjo BA, Maiga M, et al.: Roflumilast, a Type 4 Phosphodiesterase Inhibitor, Shows Promising Adjunctive, Host-Directed Therapeutic Activity in a Mouse Model of Tuberculosis. Antimicrob Agents Chemother. 2015; 59(12): 7888-7890.

PubMed Abstract | Publisher Full Text | Free Full Text

106. Maiga M, Agarwal N, Ammerman NC, et al.: Successful shortening of tuberculosis treatment using adjuvant host-directed therapy with FDAapproved phosphodiesterase inhibitors in the mouse model. PLOS One. 2012; 7(2): e30749. PubMed Abstract | Publisher Full Text | Free Full Text

107. Konrad FM, Bury A, Schick MA, et al.: The unrecognized effects of phosphodiesterase 4 on epithelial cells in pulmonary inflammation. PLOS One. 2015; 10(4): e0121725.

PubMed Abstract | Publisher Full Text | Free Full Text

108. https://www.who.int/hiv/pub/arv/adult2010/en/ AtfHiiaaaRfaphar.

109. https://aidsinfo.nih.gov/guidelines/html/1/adult-and-adolescent-arv/27/ tb-hiv GftUoAAiAaAwH.

110. Marais S, Pepper DJ, Schutz C, et al.: Presentation and outcome of tuberculous meningitis in a high HIV prevalence setting. PLOS One. 2011; 6(5): e20077. PubMed Abstract | Publisher Full Text | Free Full Text

111. Pepper DJ, Marais S, Maartens G, et al.: Neurologic manifestations of paradoxical tuberculosis-associated immune reconstitution inflammatory syndrome: a case series. Clin Infect Dis. 2009; 48(11): e96-107. PubMed Abstract | Publisher Full Text

112. https://sahivsoc.org/Files/2019\%20ART\%20Guideline $\% 2028042020 \% 20$ pdf. pdf.

113. Wilkinson RJ, Rohlwink U, Misra UK, et al.: Tuberculous meningitis. Nat Rev Neurol. 2017; 13(10): 581-598 PubMed Abstract | Publisher Full Text

114. Tobin DM, Vary JC Jr, Ray JP, et al.: The Ita4h locus modulates susceptibility to mycobacterial infection in zebrafish and humans. Cell. 2010; 140(5): 717-730.

PubMed Abstract | Publisher Full Text | Free Full Text

115. Hawn TR, Shah JA, Kalman D: New tricks for old dogs: countering antibiotic resistance in tuberculosis with host-directed therapeutics. Immunol Rev. 2015; 264(1): 344-362. PubMed Abstract | Publisher Full Text | Free Full Text

116. Tobin DM, Roca FJ, Oh SF, et al.: Host genotype-specific therapies can optimize the inflammatory response to mycobacterial infections. Cell. 2012; 148(3): 434-446. PubMed Abstract | Publisher Full Text | Free Full Text

117. van Laarhoven A, Dian S, Ruesen C, et al.: Clinical Parameters, Routine Inflammatory Markers, and LTA4H Genotype as Predictors of Mortality Among 608 Patients With Tuberculous Meningitis in Indonesia. J Infect Dis. 2017: 215(7): 1029-1039. PubMed Abstract | Publisher Full Text

118. Donovan J, Phu NH, Thao LTP, et al.: Adjunctive dexamethasone for the treatment of HIV-uninfected adults with tuberculous meningitis stratified by Leukotriene A4 hydrolase genotype (LAST ACT): Study protocol for a randomised double blind placebo controlled non-inferiority trial [version 1 peer review: 2 approved]. Wellcome Open Res. 2018; 3: 32 PubMed Abstract | Publisher Full Text | Free Full Text

119. Campo M, Randhawa AK, Dunstan S, et al.: Common polymorphisms in the CD43 gene region are associated with tuberculosis disease and mortality. Am J Respir Cell Mol Biol. 2015; 52(3): 342-348. PubMed Abstract | Publisher Full Text | Free Full Text

120. Hingorani $A D$, Kuan $V$, Finan $C$, et al.: Improving the odds of drug development success through human genomics: modelling study. Sci Rep. 2019; 9(1): 18911 PubMed Abstract | Publisher Full Text | Free Full Text

121. Kasahara M: The Production of tuberculous meningitis in the rabbit and the changes in its cerebrospinal fluid. Am J Dis Child. 1924; 27(5): 428-432. Publisher Full Text 


\section{Open Peer Review}

\section{Current Peer Review Status:}

\section{Version 2}

Reviewer Report 26 January 2022

https://doi.org/10.21956/wellcomeopenres.18684.r44724

(C) 2022 Bonnet F. This is an open access peer review report distributed under the terms of the Creative Commons Attribution License, which permits unrestricted use, distribution, and reproduction in any medium, provided the original work is properly cited.
Fabrice Bonnet
ISPED, Centre INSERM U1219, Bordeaux Population Health Research Center, University of Bordeaux, Bordeaux, France
I have no additional comments for this submission.
Competing Interests: No competing interests were disclosed.
I confirm that I have read this submission and believe that I have an appropriate level of expertise to confirm that it is of an acceptable scientific standard.

\section{Version 1}

Reviewer Report 12 April 2021

https://doi.org/10.21956/wellcomeopenres.18139.r42998

(C) 2021 Venketaraman V. This is an open access peer review report distributed under the terms of the Creative Commons Attribution License, which permits unrestricted use, distribution, and reproduction in any medium, provided the original work is properly cited.

\section{Vishwanath Venketaraman}

${ }^{1}$ College of Osteopathic Medicine of the Pacific, Western University of Health Sciences, Pomona, CA, USA

2 College of Osteopathic Medicine of the Pacific, Western University of Health Sciences, Pomona, CA, USA

This review is well-written with complete focus on the potential host directed therapies for TB meningitis. The manuscript contains a detailed literature review (both preclinical and clinical trial 
studies) on the use of corticosteroids, aspirin, thalidomide, statins, and other molecules, against TB meningitis.

Recommendations: Introducing a paragraph about tuberculosis incidence and epidemiology at the beginning of the manuscript, followed by sections on the prevalence of TB meningitis, and then pathogenesis of TB meningitis, will further enhance the strength of the manuscript.

The reviewer has provided specific comments within the text of the manuscript.

Is the topic of the review discussed comprehensively in the context of the current literature?

Yes

Are all factual statements correct and adequately supported by citations?

Yes

Is the review written in accessible language?

Yes

Are the conclusions drawn appropriate in the context of the current research literature? Yes

Competing Interests: No competing interests were disclosed.

Reviewer Expertise: Tuberculosis, HIV and Diabetes

I confirm that I have read this submission and believe that I have an appropriate level of expertise to confirm that it is of an acceptable scientific standard.

Author Response 19 May 2021

\section{Angharad Davis}

Dear Reviewer 2,

Many thanks for your thorough review of the manuscript and your suggestion to add a section on TBM epidemiology and pathogenesis.

We agree that these are important areas, however since this manuscript forms a collection of published papers in a TBM supplement, many of which covered TBM epidemiology and pathogenesis in detail, the authors felt that this manuscript should maintain a narrow focus on the subject area, and therefore felt chapters on TBM epidemiology/pathogenesis was beyond the scope of the article.

Competing Interests: No competing interests 
Reviewer Report 05 February 2021

https://doi.org/10.21956/wellcomeopenres.18139.r41926

(C) 2021 Bonnet F. This is an open access peer review report distributed under the terms of the Creative Commons Attribution License, which permits unrestricted use, distribution, and reproduction in any medium, provided the original work is properly cited.

\author{
Fabrice Bonnet \\ 1 ISPED, Centre INSERM U1219, Bordeaux Population Health Research Center, University of \\ Bordeaux, Bordeaux, France \\ 2 ISPED, Centre INSERM U1219, Bordeaux Population Health Research Center, University of \\ Bordeaux, Bordeaux, France
}

General comments:

This review regarding the host directed therapy (HDT) for TBM is globally well written and includes adequate references on this topic to date. It could be better balanced.

In the introduction, the authors could include a short chapter about TBM epidemiology.

\title{
Systematic review:
}

Title

I do not agree to consider aspirin, thalidomide and immunomodulatory therapies (anti-TNF and anti-Il1 antibodies) as "existing " HDT in TBM. To date, only one HDT has been proven to reduce mortality, namely dexamethasone and the other one are promising approaches but have not been assessed in clinical trials yet. So I would consider as Existing HDT the only dexamethasone and "Promising" HDT the other ones.

The title "potential future HDT..." should be replaced by Potential "pathways" for HDT since some of the activators/inhibitors cited in this chapter are new components never evaluated in RCTs.

\section{Chapter Dexamethasone:}

The authors should describe what kind of controls were evaluated in a study of 16 individuals in India.

The authors write about cerebral inflammation but it is a proxy to consider CSF cytokines as a maker of cerebral inflammation. The authors should comment on this point.

The issue of dexamethasone dosage (and of rifampicin induction) and of the use of other corticosteroids should be detailed in this chapter described since dexa is the only HDT validated in the guidelines.

\section{Chapter Aspirin:}

The chapter is well written.

In addition to the comprehensive antiagregant effect of aspirin, can the author explain how they expect an additional antiinflammatory effect to high dose dexamethasone? The duration of the treatment should be discussed.

\section{Chapter Thalidomide:}

Data on thalidomide are very few and mainly observed in children.

The authors should be cautious regarding their experience with adjunctive thalidomide in TBM 
regarding the lack of date. Thalidomide is an old anti-inflammatory drug used in inflammatory diseases and progressively removed from guidelines because of its toxicity. Again, it seems difficult to consider thalidomide as a "promising" drug for TBM since new biological agents are far more efficient on proinflammatory cytokines.

The authors should not suggest using thalidomide at a large scale in TBM/TB brain abscess.

\title{
Chapter Immunomodulatory HDT:
}

This chapter is quite short regarding the perspective given by anti-TNF in a severe form of TBM/CNS TB. The choice of the type of anti-TNF, as well as the duration of treatment and the risk associated to this medication, could be discussed. To my mind, anti-TNF therapies may represent one of the best approaches to reduce mortality and morbidity of TBM/TB Abssess in HIV and non HIV people and in children. The main issues are the toxicity of these drugs in the environment where TBM occurs and the availability of these drugs in poor income countries. These points have to be discussed in this review.

In table 2, the authors should add the following references about adalimumab:

Adalimumab treatment may replace or enhance the activity of steroids in steroid-refractory

tuberculous meningitis. Lee HS, Lee Y, Lee SO, Choi SH, Kim YS, Woo JH, Kim SH. J Infect

Chemother. 2012 Aug;18(4):555-7

Adalimumab for Corticosteroid and Infliximab-Resistant Immune Reconstitution Inflammatory Syndrome in the Setting of TB/HIV Coinfection. Lwin N, Boyle M, Davis JS. Open Forum Infect Dis. 2018 Jan 30;5(2): ofy027

\section{ART:}

It is not really fair to consider ART as HDT... even if it is obvious that ART has a significant impact on immunological status. HIV coinfection raises other issues in the management of TBM and I would consider separating this chapter from HDT.

\section{Chapter Future pathways...:}

Chapter Statin therapy

It is not well balanced to have a chapter statin with no data on TBM longer than the chapter on biological agents, even if the background is interesting.

I would summarize the impact of statin on multiple sclerosis, brain injury, etc since it is quite far from TBM to focus on the potential interest of statins on TB and immune response.

FIGURE 2: Not really helpful in the present form.

I would perform a central plot with increased neuronal survival, immune modulation, axon plasticity myelination that are the goal of treatment; and to describe around the central plot the different pathways to reach this target.

\section{Chapter Host response:}

The discussion regarding the LTA4H gene and the response to dexamethasone is an important point of pharmacogenetic. The authors should discuss if this strategy is affordable in every setting.

\author{
Is the topic of the review discussed comprehensively in the context of the current \\ literature? \\ Yes
}

Are all factual statements correct and adequately supported by citations? 


\section{Partly}

Is the review written in accessible language?

Yes

Are the conclusions drawn appropriate in the context of the current research literature? Yes

Competing Interests: No competing interests were disclosed.

Reviewer Expertise: HIV Infection ; TBM

I confirm that I have read this submission and believe that I have an appropriate level of expertise to confirm that it is of an acceptable scientific standard, however I have significant reservations, as outlined above.

Author Response 19 May 2021

\section{Angharad Davis}

Dear reviewer 1 ,

Many thanks for your thorough review of the manuscript and your suggestions. We have addressed each in turn in the responses below.

\section{General comments:}

This review regarding the host directed therapy (HDT) for TBM is globally well written and includes adequate references on this topic to date. It could be better balanced.

In the introduction, the authors could include a short chapter about TBM epidemiology.

We agree that this is an important area, however since this manuscript forms a collection of published papers in a TBM supplement, many of which covered TBM epidemiology in detail, the authors felt that this manuscript should maintain a narrow focus on the subject area, and therefore felt a chapter on TBM epidemiology was beyond the scope of the article.

\section{Paragraph sub-headings:}

I do not agree to consider aspirin, thalidomide and immunomodulatory therapies (anti-TNF and anti-Il1 antibodies) as "existing " HDT in TBM. To date, only one HDT has been proven to reduce mortality, namely dexamethasone and the other one are promising approaches but have not been assessed in clinical trials yet. So I would consider as Existing HDT the only dexamethasone and "Promising" HDT the other ones.

The title "potential future HDT..." should be replaced by Potential "pathways" for HDT since some of the activators/inhibitors cited in this chapter are new components never evaluated in RCTs.

We have changed the sub-headings as suggested. 


\section{Chapter Dexamethasone:}

The authors should describe what kind of controls were evaluated in a study of 16 individuals in India.

This has been added to this section.

The authors write about cerebral inflammation but it is a proxy to consider CSF cytokines as a maker of cerebral inflammation. The authors should comment on this point.

A comment has been added to this section as per suggestion .

The issue of dexamethasone dosage (and of rifampicin induction) and of the use of other corticosteroids should be detailed in this chapter described since dexa is the only HDT validated in the guidelines.

We agree this issue is important and have commented on this in the text pointing out to readers that although "Corticosteroid use in TBM is commonplace, dexamethasone is commonly used as it is affordable and widely available although the optimal corticosteroid preparation, dose, and route of administration are unknown." We have added text to further clarify this point in a sentence following this.

\section{Chapter Aspirin:}

The chapter is well written. In addition to the comprehensive antiagregant effect of aspirin, can the author explain how they expect an additional anti-inflammatory effect to high dose dexamethasone? The duration of the treatment should be discussed.

Many thanks. These suggestions have been added to this section.

\section{Chapter Thalidomide:}

Data on thalidomide are very few and mainly observed in children.

The authors should be cautious regarding their experience with adjunctive thalidomide in TBM regarding the lack of date. Thalidomide is an old anti-inflammatory drug used in inflammatory diseases and progressively removed from guidelines because of its toxicity. Again, it seems difficult to consider thalidomide as a "promising" drug for TBM since new biological agents are far more efficient on proinflammatory cytokines.

The authors should not suggest using thalidomide at a large scale in TBM/TB brain abscess.

Many thanks for your comments on this. We feel differently that the use of thalidomide is supported by now numerous published studies, the most recent being the largest cohort of adult or pediatric patients treated with adjunctive thalidomide for CNS TB-related complications. In this study (reference below), published this year in Clinical Infectious Diseases, thalidomide appeared to be safe, well tolerated and clinically efficacious. Although we appreciate that further RCT generated evidence is required to warrant its use widescale, 
it is the opinion of the authors on the manuscript that this is indeed a 'promising' HDT that warrants discussion and further explanation.

Ronald van Toorn, Regan S Solomons, James A Seddon, Johan F Schoeman. Thalidomide Use for Complicated Central Nervous System Tuberculosis in Children: Insights From an Observational Cohort. Clinical Infectious Diseases, Volume 72, Issue 5, 1 March 2021, Pages e136-e145

\section{Chapter Immunomodulatory HDT:}

This chapter is quite short regarding the perspective given by anti-TNF in a severe form of TBM/CNS TB. The choice of the type of anti-TNF, as well as the duration of treatment and the risk associated to this medication, could be discussed. To my mind, anti-TNF therapies may represent one of the best approaches to reduce mortality and morbidity of TBM/TB Abssess in HIV and non HIV people and in children. The main issues are the toxicity of these drugs in the environment where TBM occurs and the availability of these drugs in poor income countries. These points have to be discussed in this review.

In table 2, the authors should add the following references about adalimumab: Adalimumab treatment may replace or enhance the activity of steroids in steroid-refractory tuberculous meningitis. Lee HS, Lee Y, Lee SO, Choi SH, Kim YS, Woo JH, Kim SH. J Infect Chemother. 2012 Aug;18(4):555-7

Adalimumab for Corticosteroid and Infliximab-Resistant Immune Reconstitution Inflammatory Syndrome in the Setting of TB/HIV Coinfection. Lwin N, Boyle M, Davis JS. Open Forum Infect Dis. 2018 Jan 30;5(2):ofy027

Many thanks for these comments. These references have been added as suggested.

\section{ART:}

It is not really fair to consider ART as HDT... even if it is obvious that ART has a significant impact on immunological status. HIV coinfection raises other issues in the management of TBM and I would consider separating this chapter from HDT.

Many thanks for these comments. As per your suggestion we have separated this section as a distinct sub-chapter within the manuscript.

\section{Chapter Future Pathways:}

Chapter Statin therapy - It is not well balanced to have a chapter statin with no data on TBM longer than the chapter on biological agents, even if the background is interesting. I would summarize the impact of statin on multiple sclerosis, brain injury, etc since it is quite far from TBM to focus on the potential interest of statins on TB and immune response.

Thank you for these comments, we have shortened this paragraph as suggested.

FIGURE 2: Not really helpful in the present form.

I would perform a central plot with increased neuronal survival, immune modulation, axon 
plasticity myelination that are the goal of treatment; and to describe around the central plot the different pathways to reach this target.

Many thanks for your thoughts on this. We agreed with these and attempted to modify the figure as you suggested. However, on review, given that the effect of manipulation of these pathways has not yet been explored in this context we did not want to develop a figure which may be misleading given the early stages of research in this area. We have rather simplified the diagram as a reference figure for readers as they read this section, allowing them to visualise the pathways being discussed.

\section{Chapter Host response:}

The discussion regarding the LTA4H gene and the response to dexamethasone is an important point of pharmacogenetic. The authors should discuss if this strategy is affordable in every setting.

Many thanks, we agree this is an important issue; we have added a comment on this to the section.

Competing Interests: Nil competing interests 